\title{
Matthew as marginal scribe in an advanced
}

\section{agrarian society}

\author{
D C Duling ${ }^{1}$ \\ Canisius College, Buffalo, New York, USA \\ Research Associate: Department of New Testament Studies \\ University of Pretoria
}

\begin{abstract}
Analysis of 22 references to scribes in the Gospel of Matthew shows that a few of them are positive comments and that the author himself was a scribe. What type of scribe was he and how can we clarify his social context? By means of the models of Lenski and Kautsky, by recent research about scribes, literacy, and power, and by new marginality theory, this article extensively refines Saldarini's hypothesis that the scribes were "retainers". The thesis is that in "Matthew's" Christ-believing group, his scribal profession and literacy meant power and socioreligious status. Yet, his voluntary association with Christ believers ("ideological marginality"), many of whom could not participate in social roles expected of them ("structural marginality"), led to his living between two historical traditions, languages, political loyalties, moral codes, social rankings, and ideologicalreligious sympathies (“cultural marginality"). The Matthean author's cultural marginality will help to clarify certain well-known literary tensions in the Gospel of Matthew.
\end{abstract}

\section{INTRODUCTION}

In 1993 I published a paper titled "Matthew and Marginality" in the SBL Seminar Papers (Duling 1993b); two years later, it appeared with minor revisions in Hervormde Teologiese Studies (Duling 1995b). At the time, "marginality" was beginning to be used

\footnotetext{
1 Paper presented at the International Context Group Meeting at the University of Pretoria, June 2001. Prof Dr Dennis C Duling visited South Africa as Research Associate of Prof Dr Andries G van Aarde, Department of New Testament Studies, Faculty of Theology, University of Pretoria.
} 
in Biblical study without much knowledge or understanding of its rich social-scientific history and many faceted usage. In part, I wanted to fill this lacuna for New Testament scholars. With Gerhard Lenski's macrosocial model of an advanced agrarian society and models of small groups a backdrop (Lenski 1966; Lenski and Lenski 1987), I developed three senses of term and conceptuality of "marginality":

- involuntary marginality, the most familiar meaning of marginality, which included not only artisans, the poor and dispossessed, and the unclean, but also those at any level of the social structure who according to commonly accepted criteria were denied the opportunity to participate in roles expected of them (Germani 1980);

- voluntary marginality, applied the individuals and groups who choose "outsiderhood," that is, to not live according to commonly accepted norms, beliefs, and behaviors of the larger society (Victor Turner 1969); and

- "Marginal Man," an individual who, because of birth, migration, or conquest is "doomed" to live between two or more competing normative schemes, that is, two or more historic traditions, languages, political loyalties, moral codes, or religions" (Stonequist 1937; developed from Park 1928; 1931). This concept, typified by the experience of "in between-ness", was historically the basis for the other analytical conceptions of marginality.

At the end of the article I suggested that the Matthean author was a scribe who freely associated with a Jesus Messianic group (2: voluntary marginality). I noted that this group included (in Lenski's terms) retainers, artisans, peasants, expendable persons, and the unclean (1: involuntary marginality). Finally, I proposed that the author himself was an "in between" person, a person of "status incongruity" (3: "Marginal Man"). He found himself between elite and the lower illiterate strata, between literate scribes and illiterate peasants, between men and women, between growing normative Pharisaism and his Jesus group, between Semitic and Greek languages, between Judaean and Greco-Roman culture - in general between what is old and what is new (13:52). In another article, "The 
Matthean brotherhood and marginal scribal leadership" (Duling 1995a), ${ }^{2}$ I suggested that this "marginal scribe" provided leadership for a voluntary association perceived as "marginal" by the larger society, but especially the rival Pharisees.

I have since developed my understanding of both marginality ${ }^{3}$ and scribes. I now want to refine my view that the Matthean author was a marginal scribe in a marginal group in an advanced agrarian society.

\section{SCRIBES IN THE GOSPEL OF MATTHEW AND IN THE MATTHEAN CONTEXT}

Any scholar who takes the view that the author of the First Gospel was a marginal scribe in an advanced agrarian society must first take a position on how this author evaluates scribes. This is a matter of some disagreement in Matthean scholarship. The best, earliest manuscripts of Matthew contain 22 references to the term grammateus, "scribe."4 For convenience, I distribute them as follows: ${ }^{5}$

\footnotetext{
2 A few scholars have built on my studies; see Arlandson (1997); Vledder (1997 passim); Warren Carter (1994, 1997b, 2000 passim (esp 18, building on Arlandson's modifications, and 43-49); Wainwright (1999); Hertig (1997, 1999); Senior (1999). Several surveys of recent Matthew research have noted or highlighted the 1993 paper; see Anderson (1995:173, 174; 1998); Senior (1998a, 1998b, 1999:21). In 1999 the Matthew Group of the Society of Biblical Literature at Boston devoted its whole session to marginality, and the 1993 paper was often cited as foundational.

3 I pursued the social-scientific concepts further in "Marginality revisited," Context Group, Portland, OR (March 16, 1990) with special attention to Billson (1988), Berry (1990), and Lee (1995). For recent studies of scribes, see below.

4 Mt 23:14, omitted by Aleph, B, and others, is usually judged to be a copyist's interpolation based on Mark 12:38a, 40 ("Beware of the scribes ... who devour widows' houses and for a pretense make long prayers. They will receive the greater condemnation.") or its parallel, Luke 20:46a, 47. The verse is now placed in the Nestle-Aland apparatus.

${ }^{5}$ Refined from my analysis in Duling (1995a).
} 


\section{A. Parallels with Mark \\ 1. Direct parallels}

2. Indirect parallel?

B. Deletions from Mark

1. The term itself

2. Term in deleted clauses

C. Substitutions of Mark

1. By "Pharisees"

2. By "elders of the people"

D. No parallels

1. In a $\mathrm{Q}$ context

2. In another context

E. No links to other groups

1. Markan parallels

A. Scribes $=$ opponents

B. Scribes neutral

2. No Markan parallels

F. Links to other groups: Markan parallels:

1. "Pharisees and scribes"

2. "High Priests and scribes"

3. "scibes and elders"

4. "elders, High Priests, and scribes"

5. "High Priests, scribes, and elders"

G. Links other groups:

No Markan parallels:

1. "High Priests and scribes"

2. "scribes and Pharisees:
$10 \mathrm{x}$

9x $\quad 7: 29($ Mk 1:22); 9:3 (Mk 2:6); 15:1a (Mk 7:1); 16:21 (Mk 8:31); 17:10 (Mk 9:11); 20:18 (Mk 10:33); 21:15 (Mk 11:18); 26:57 (Mk 14:53); 27:41 (Mk 15:31)

$1 \mathrm{x}$ 23:2 (Mk 12:38?)

$7 x$

4x 9:11 (Mk 2:16); 21:23 (Mk 11:27); 26:47 (Mk 14:43); 27:1 (Mk 15:1)

3x 15:1b (Mk 7:5); 17:14 (Mk 9:14); 22:40 (Mk 12:32)

$4 \mathrm{x} / 5 \mathrm{x}$ $3 x / 4 x$

$1 \mathrm{x}$

9:34/12:24 (Mk 3:22: "scribes"); 22:41 (Mk 12:35: "scribes"); 22:34 ("lawyer of the Pharisees"; Mk 12:28 "one of the scribes")

26:3 (Mk 14:1); cp. 26:47; 27:1

$12 \mathrm{x}$

$9 x$

8:19 (Q 9:57); 12:38 (Q 11:16); 23:13, 15, 23, 25, 27, 29, 34 (Q 11:39b-44, 46-52).

$3 x$

$2: 4 ; 5: 20 ; 13: 52$

$5 x$

$3 x$

$2 \mathrm{x}$

Mt 9:3 (Mk 2:6); 7:29 (changes "the scribes" in Mark 1:22 to "their scribes")

1x $\quad$ Mt 17:10 (Mk 9:11)

2x Mt 8:19; 13:52

$6 x$

\begin{tabular}{|c|c|}
\hline $1 \mathrm{x}$ & 15:1 (Mk 7:1) \\
\hline $2 \mathrm{x}$ & $20: 18($ Mk 10:33); 21:15 (cf Mk 11:18) \\
\hline & 26:57 (Mk 14:53 [+ High Priests]) \\
\hline & $16: 21(\mathrm{Mk} 8: 31)$ \\
\hline & 27:41 (Mk 15:31) \\
\hline
\end{tabular}

$10 \mathrm{x}$ $\begin{array}{ll}1 \mathrm{x} & 2: 4 \\ 9 \mathrm{x} & 5: 20 ; 12: 38 ; 23: 2,13,15,23,25,27,29\end{array}$

This distribution shows that almost half of the 22 Matthean references (10x) are from Mark (A, which are almost half of Mark's references [21x; A + B, C]). Slightly more than half Matthew's references $(12 \mathrm{x})$ are found only in Matthew (D), most of them $(9 \mathrm{x})$ 
distributed in $\mathrm{Q}$ contexts (D1). In five cases, the Matthean scribes stand alone (E). In two of them, both from Mark (E1A), scribes are clearly opponents. Indeed, most Matthean references to scribes (16x) yoke them with opponents of Jesus (F, G). Scholars usually agree that the Matthean author has created the majority of these "opponent links" (esp G2); that most of them are with the Pharisees (G), the usual Matthean opponents; and that this result corresponds with that fact that Pharisees are the usual substituted opponents (C). In this connection, the Matthean author omits the "good scribe" passage from Mark, that is, the scribe "who is not far from the Kingdom" (Mark 12:32-34).

This mixed data has produced a debate. Some scholars conclude that the Matthean author was not clear (Walker 1967; Van Tilborg 1972) or was even confused about these groups (Cook 1978:58-67); others say that he intentionally distorted Jesus' opponents to show that they formed a "united front." However, David Orton is representative of scholars of the opposite opinion, such as Saldarini and Overman, when he writes, "... the scribes per se never stand alone as opponents of Jesus. They are tainted by the company they keep" (Orton 1989:28). The bad company is especially the sect of the Pharisees. ${ }^{7}$

I accept this more positive view of the scribes for four reasons:

- Some of Matthew's created links about scribes - with Pharisees in polemical contexts and elders in Jerusalem - are in a general way historically plausible. ${ }^{8}$

- Matthew omits Mark's "good scribe" passage because he has just transformed him into a Pharisaic lawyer who tests Jesus (Mt 22:34-35 [Mk 12:28]).

\footnotetext{
${ }^{6}$ Meier (1991:19) thinks that Matthew's linking of Pharisees and Sadducees (Mt 3:7; 16:1, 6, 11, 12) is "unhistorical".

7 Saldarini (1988b); Overman (1990); Orton (1989); Saldarini (1988: 267, n 67 also notes Hummel 1963:17-18); Van Tilborg (1972:128-47); Hengel (1985:78-81). Matthew's deletions and his replacements of scribes with Pharisees (see $\mathrm{C}$ and $\mathrm{G}$ in list above) are related to his persistent anti-Pharisaic polemic (e $\mathrm{g}$, $9: 11,34 ; 12: 24,38 ; 15: 12 ; 16: 11 ; 21: 45 ; 22: 15,34-35 ; 27: 62)$.

8 Deletions of "scribes" with "chief priests and elders" in Jerusalem settings (21:23 [Mk 11:27]; 26:3 [Mk 14:1] 26:47 [Mk 14:43]; 27:1 [Mk 15:1]) and replacing scribes with Pharisees or narrowing to the Pharisees (15:12, cp 15:1) in conflict stories about purity $(9: 11$ [Mk 2:16]) are quite plausible. See Saldarini (1988:160-61); Orton (1989:26).
} 
- Two of five cases where scribes stand alone and are sometimes said to be opponents can be interpreted differently. One refers to "their scribes" (Mt 7:29) which refers to scribes of the Pharisees ${ }^{9}$ and the other qualifies by the expression "some of the scribes" (Mt 9:12 [Mk 2:6]).

- Most importantly, there are five scribe passages that are arguably positive. In an ascending order of importance these are:

* Matthew accepts the scribal view in Mark that Elijah is the forerunner of the Messiah (Mt 17:10 [Mk 9:11]; Matthew interprets him to be John the Baptist);

* only Matthew's Jesus' says that the scribes and Pharisees sit on Moses' seat and the crowds and disciples should practice and observe what they teach (Mt 23:2); ${ }^{10}$

Matthew alone inserts "a scribe" into the Q sayings about the difficulty of "following" Jesus (Mt 8:19; cp Q-Luke 9:57-60), and I agree with those who argue that this saying implies that the follower is a disciple; ${ }^{11}$

* Matthew changes Q's itinerant "prophets and apostles" sent out by Jesus to "prophets, sages, and scribes" (Q 11:49; Mt 23:34). ${ }^{12}$

9 See "their synagogues" (4:23; 9:35; 10:17; 12:9; 13:54); “your synagogues" (23:34); "their cities" (11:1; cf 12:38) (Kilpatrick 286; Stanton 1992:119-20, 128; Overman 1990:115).

${ }^{10}$ There is negativity here, but it is related to the link with the Pharisees and, despite their reputed hypocrisy, their teaching is said to be correct. Matthew is not always totally consistent, of course (see Hummel 1963:31; Garland 1979:20-22, 46-55).

${ }^{11}$ For the negative view of the scribe in Mt 8:19, see Kingsbury (1978:59-60; 1988; Luz 1990:23; Davies \& Allison 1991:2.41, 53-54; Kiilunen 1991; Stanton 1992a:383; 1992b:127; Carter 1994:52; 1996: 66). For the positive view, see Saldarini (1988:159). Also, Orton emphasizes that grammatical changes - from Q's indefinite "someone" (tis) to definite "one scribe" (heis grammateus), as well as from Q's "another" to "another of the disciples," indicate that the scribe is a disciple (Orton 1989:36-37). Robert Gundry (1994b) has offered the most finely tuned grammatical and redactional analysis, suggesting that there are two scribes, the first good, the second bad. For a summary of his detailed arguments, see Duling (1995a). On the "foxes have holes..." saying (v 20), see GTh 86; Kloppenborg (1988:65).

12 "Prophets" occur 37 times, 20 of which are perhaps redactional. They are generally viewed with favor (Luz 1989:67). Matthew's warnings are about false prophets (7:15-23; cf 24:11-12, 24); (see Bornkamm 1963:39 n 1; Schweizer 1970; Hill 1976; Overman 1990:118). The term "sages" (sophoi) occurs negatively in Mt 11:25 (= Q 10:21), but they are sages of the world, probably Pharisaic sages $(12: 2,14,24,38$ ) (so Suggs 1970: 84-87; see also Overman 1990:117). 
Finally, Matthew composed the formulaic conclusion to the third speech, which speaks in Mt 13:52 of a scribe "instructed as a disciple" for the kingdom of heaven" (Kingsbury 1969:126-27; Gundry 1994:281; Luz 1983:109). Dan Harrington (1991:208) represents a very widespread view when he writes that this description is a "self portrait of the evangelist."13 I agree.

Thus, while most scribes in Matthew are viewed negatively because of their association with Jesus' opponents, some are seen as positive and, indeed, it is very probable that the author of the Gospel himself was a scribe. This conclusion allows me to go forward with the view that the author of Matthew was a marginal scribe in an advanced agrarian society.

\section{SCRIBES AS MEMBERS OF THE "RETAINER CLASS" IN AN ADVANCED AGRARIAN SOCIETY}

Macrosociologist Gerhard Lenski $(1966,1988,1994)$ holds the view that humans cooperate in order to survive, that cooperation requires a necessary division of labor in the production of resources, and that competing self or group interest leads to the quest for power, or carrying out one's individual or social will, even when opposed by others. ${ }^{14}$ Those who gain power also gain control of the economic surplus for their own benefit, despite occasional nods to altruism (for example, concern for the poor). Those in power also grow in social privilege, though there are other necessary variables. Finally, both power and privilege yield prestige. A feedback loop shows how prestige feeds still greater power. In its simplest form, the dynamics of the distribution of valued resources based on power, privilege, and prestige looks like Model I (Lenski 1966:43):

13 The representatives of this view are legion. They include Hoh (1926); Bacon (1930: ch 10); Kilpatrick (1950:111); Stendahl (1968:30, 34 n 4); Hummel (1963:17-18, 26-28); Trilling (1964:146); Strecker (1966:30, 37, 192); Kingsbury (1973:166, n 149); Overman (1990:116); Orton (1989).

14 Lenski (1994:10-13) described his perspective as "materialist" in the tradition of archeologist V Gordon Childe and anthropologist Walter Goldschmidt. Sociological theorist JonathanTurner (1984:54-55, 81, 84, 158-159; Preface ii, 49), who acknowledges that the single most important influence on him was Lenski, finds Lenski's synthesis to be especially attractive. Turner (1984:61-62) adds that the more complex the society, the more important are political power and material wealth for understanding the dynamics of the social system. 


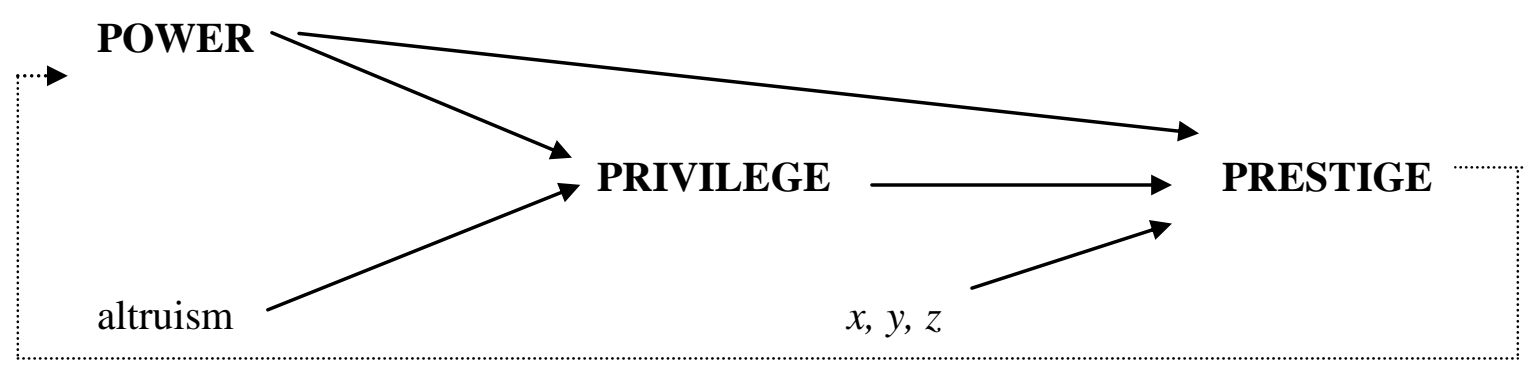

Model I: The Dynamics of Distribution Systems (Lenski 1966:45)

For Lenski (1988:169; see also 1994:22, 23), “... variations in subsistence technology have been the most powerful single cause of variations in societal systems of stratification in the total universe of human societies, past and present." 15 Acknowledging the importance of other developments (the wheel, the harnessing of animal and wind power, writing, and the calendar), Lenski thinks that the plow was the most important technological innovation for the shift from horticulture to agriculture in the fourth millennium BCE. The invention of the iron-tipped plow in the late second millennium led to advanced agrarian societies. Economically, there was greater division of labor, growth in business, commerce, and more migration to increasingly larger cities. Politically, there emerged the proprietary theory of the state, growth of the elites' administrative staffs and retainers, greater exploitation of peasants, and occasional peasant unrest. The family lost some of its integrating power, though it was still economically important. In religion there was greater universalism, religious legitimation of the state, decline in theocracy, and the growth of magic and fatalism. Thus, the simple agrarian society became an advanced agrarian society, as in Model II:

15 Lenski was aware that subsistence technology was not the whole story. It had to be related to environment, that is, ecosystems; plow agriculture did not develop in the tropics! 


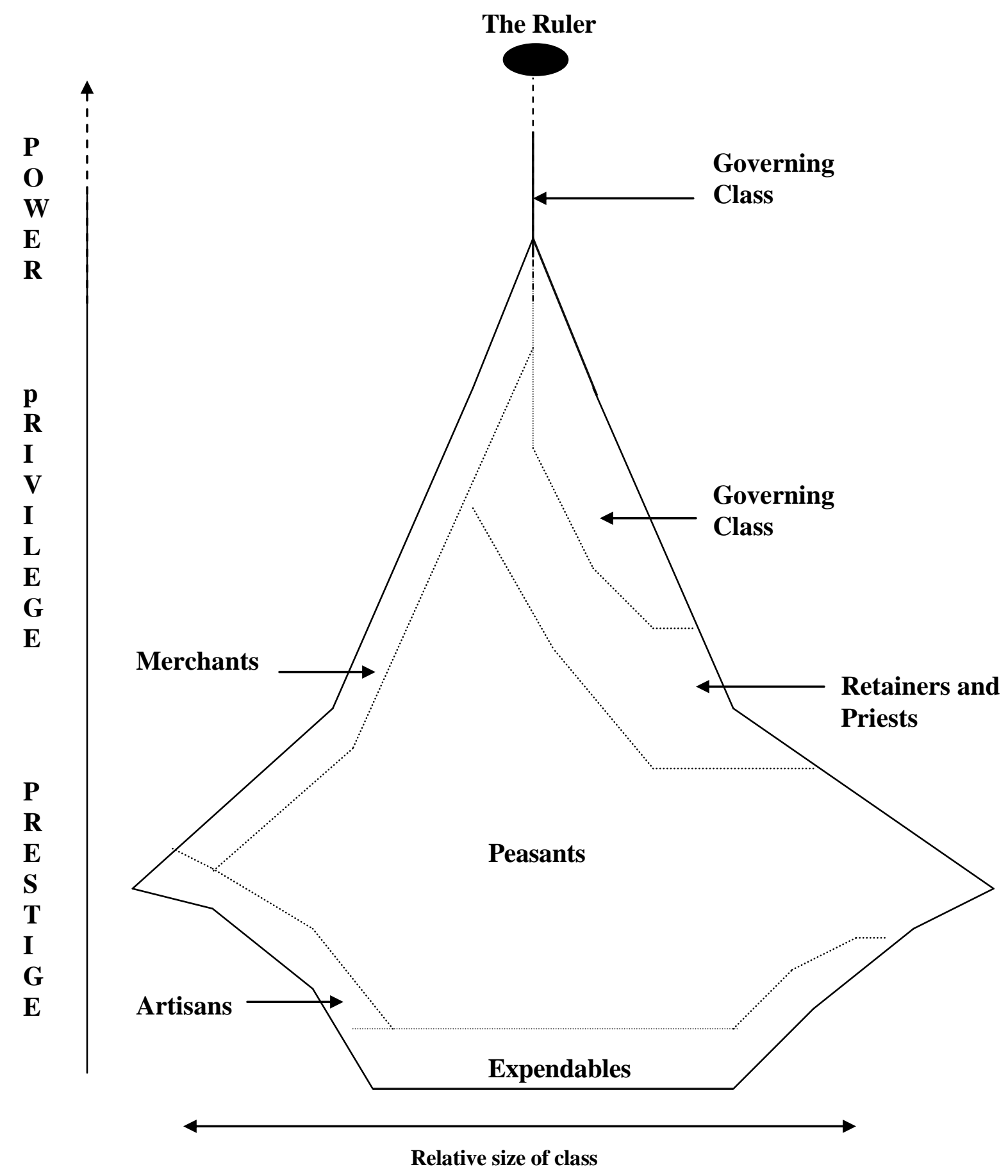

Model II: Lenski's Advanced Agrarian Society

(Nolan and Lenski 1999:190 [see Lenski 1966:284])

This simple model focuses on social stratification as it relates especially to politics and economics. It simplifies historical information in order to facilitate understanding and 
analysis (Lenski 1966:284) ${ }^{16}$ However, says Lenski, people actually rank each other in a variety of ways, or what he calls "classes." ${ }^{17} \mathrm{He}$ defines "class" as "an aggregation of persons in a society who stand in a similar position with respect to some form of power, privilege, and prestige" (Lenski 1966:75). Within "class" he includes rankings based on "status groups" (Max Weber: Stände) that develop distinctive subcultures and are likely to be hereditary. Examples of "class systems" are family, gender, occupation, race, ethnicity, and religion (Lenski 1966:78). ${ }^{18}$ In this simple political-economic model "class systems" are not visible.

To illustrate some of the class variables, Lenski (1966:82) imagines a fictional society and ranks people in it based on politics, wealth, occupation, and ethnicity. He theorizes that there are also differences within these "class" systems, for example, the degree of complexity, range of vertical stratification ("span"), the pattern of distribution ("shape"), degree of mobility, and degree of institutionalization (ideologically-based custom or law). Moreover, each class system can be assigned a different weight of importance and can be configured differently. All of these variables together form a distributive system. Lenski's fictional distributive system, derived from a Latin American society, has some parallels to ancient agrarian societies. I have revised his fictional chart to more closely approximate an ancient advanced agrarian society, adding several class systems and changing some weights (Chart I). Following Malina's view that politics and

16 Lenski (1988:166) holds it to be fundamental that theory should be based on empirical data. For my view of models, see Duling (1992:99-102); Arlandson (1997:21-22). I based my hermeneutic of modeling on Carney (1975); Galt and Smith (1976); Elliott (1986); and Malina (1981, 1986). Models are useful for creating theory and testing it, but they are not theory. They are most useful for closed systems where variables are known and can be clearly related (sSee Turner 1984:10).

17 Most analysts of the ancient Mediterranean prefer the term "status" to "class" because "class" has Marxist overtones that do not apply to antiquity and there was no large middle class (see Finley 1973:49; Meeks 1983:53-54; Alföldy 1985:99; MacMullen 1974:89, 94). Rohrbaugh (1984:534, 537, 542) thinks that Lenski's "power class" is acceptable for antiquity if one defines it in terms of a political-economic interest group that controls the economic surplus. Social theorist Jonathan Turner (1984:146) also prefers not to use the term "class"; however, he continues to use it because of its prevalence in the social sciences.

${ }^{18}$ Lenski also thinks that class can include "caste" and "estate." "[A] ... class is a caste to the degree that upward mobility into or out of it is forbidden by the mores ( Lenski 1966:77). "[A] ... class is an estate to the degree that its existence, rights, and privileges are established by law" (Lenski 1966:78). 
kinship are the two most important social domains in the Mediterranean world, ${ }^{19} \mathrm{I}$ have weighted them (and gender) heavily.

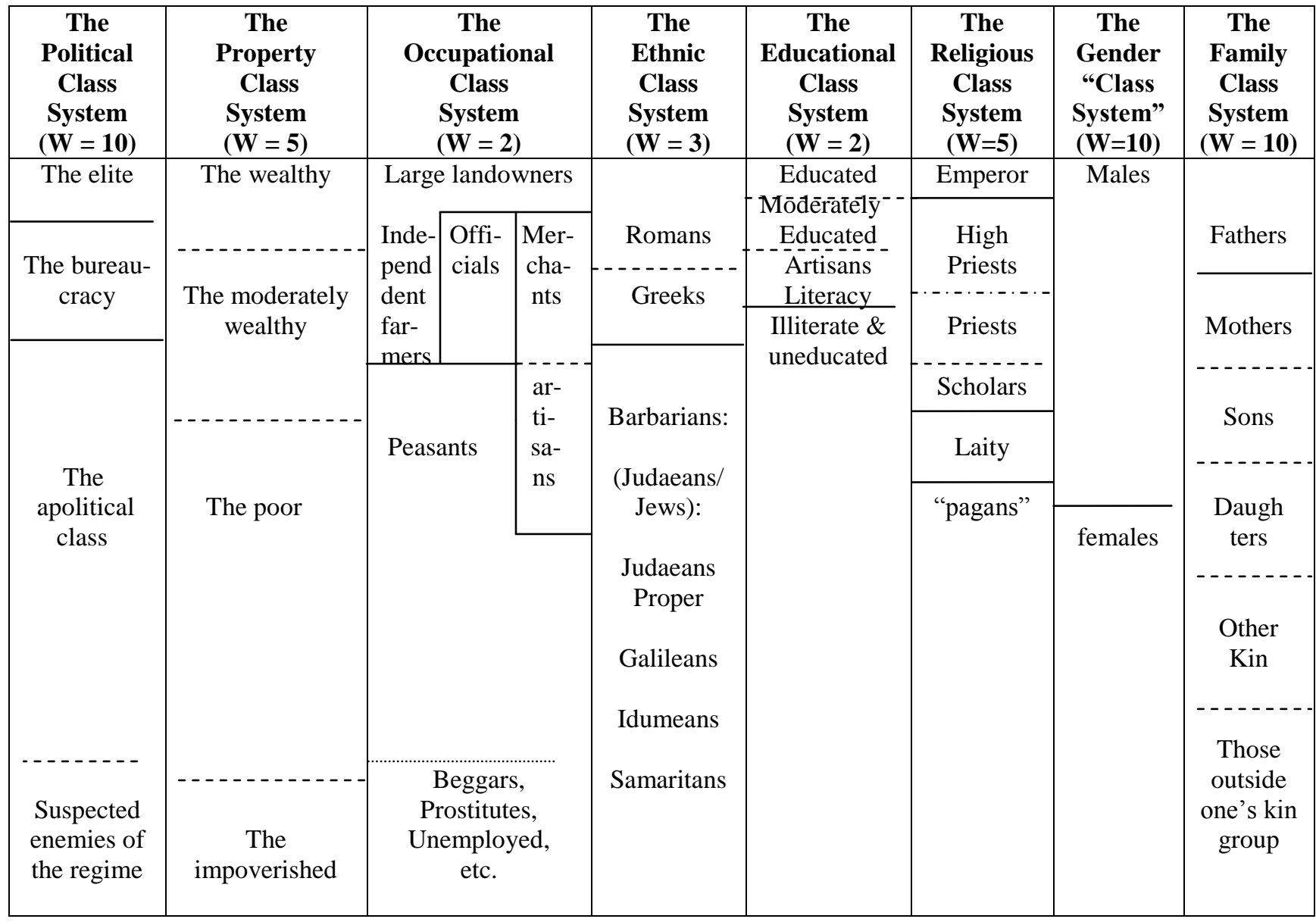

Chart I

A Fictional Distributive System (Modified from Lenski 1966:80)

( $w$ = weight of importance from 2-10)

In short, all the class systems together, not just the political and economic systems in the abstract macromodel, form the "distributive system." A person's ranking in several class systems is usually coordinate with political and economic power in the macromodel, though not always and necessarily. There is also some positive correlation between class systems. However, there can also be competition among the various class rankings and

19 For Malina (1986:86) social domains such as religion, economics, and education in Mediterranean antiquity did not exist as separate, differentiated, and distinctive social institutions, but were "embedded" in politics and religion. 
there can be local variations and ethnocentric rankings. ${ }^{20}$ Weights can change in specific contexts. Ranking of Greeks and Romans within the Judaean [Jewish] version of the ethnic/religious class system looks different from ranking in the more general distribution system (Chart I). When ranking is relatively high in one class system and relatively low on another - in actual versus fictive kin relations, for example - "status dissonance," says Lenski, can result. This is a recurring feature, as we shall see, in marginality.

The key question for this study is: how should ancient scribes be ranked? As Saldarini (1988:169; see also Lenski 1994:22, cp p 23) emphasized, that question is easily answered in the simplified macromodel above: in the retainer class. This class contains an odd assortment of officials: professional soldiers, government bureaucrats, household servants, and petty officials, including tax collectors. ${ }^{21}$ What unites them is that they serve the elite and function as social brokers between the rulers and the ruled. For example, they collect the economic surplus and deflect resentment about elite power, privilege, and prestige on the part of the lower social strata. As their reward they receive a greater share in the economic surplus and a higher status than the masses. Lenski estimates that the retainers make up about $5 \%$ of the population.

It is important to ask the ranking question not only in the macrosocial system the advanced agrarian society - but in relation to Lenski's "classes" in the "distribution system." Lenski macrosocial analysis does not address this question in detail and thus he does not analyze the ranking of scribes in particular (see Turner's criticism, footnote 20); thus, more needs to be said.

In the occupational class system scribes are "officials." In the educational class system they are among the literate elite, though not at the very top. In the family class system, there can be scribal families. In the gender class system, scribes are almost all male. $^{22}$ Finally, in various ethnic and religious class systems scribes can be higher in

\footnotetext{
20 Lenski's macro-analysis has received some criticism. Jonathan Turner (1984:54; Preface ii, 49), for example, thinks that his abstract level of analysis sometimes obscures his "class systems". I have attempted to address this problem by making suggestions about the distribution system.

${ }^{21}$ Because of this variety, status ranking within any class is difficult. Military experts and literates receive some status enhancement and corresponding wealth, though wages are mostly modest. They also compete with each other and continually seek to maximize their rights and privileges; such ambitions threaten the ruling classes only in the case of the military. Despite such difficulties I shall distinguish several kinds of scribes.

${ }^{22}$ See, however, the study of Haines-Eitzen (1998) noted below for women copyists.
} 
status. I will explore some of these dimensions further. First, however, I want to note how Lenski's ranking of scribes in the larger ranking system has been used in scholarship on Mediterranean society and the New Testament.

\section{THE USE OF LENSKI FOR ANALYZING THE SCRIBES IN MEDITERRANEAN SOCIETY}

Not surprisingly, Greco-Roman society is Lenski's key example of an advanced agrarian society. ${ }^{23}$ A number of scholars have used Lenski's model - the first New Testament scholar seems to have been Rohrbaugh (1978) in the late 1970s - and some have combined it with John Kautsky's view of "aristocratic empires," ${ }^{24}$ as a way to interpret social structures and relations in ancient Mediterranean society, including more localized Judaean and early Jesus Movement groups. ${ }^{25}$ Here are two examples in which scribes are ranked:

${ }^{23}$ The most recent revision of the classic Lenski textbook (Nolan \& Lenski 1999), uses the Roman Empire as its most common illustration of an advanced agrarian society (see Nolan \& Lenski 1999:166, 167, 169, 170, 173, 175, 176, 177, 180; see also Lenski 1966:198).

24 John Kautsky (1982), a political scientist, is indebted to Lenski's views of societal evolution. Lenski read Kautsky's manuscript before publication (Kautsky 1982:xvi; cp p 7, n 7; 19-20, 27). However, Kautsky also draws on Sjoberg (1960), Eisenstadt (1963, 1978), Bendix (1978), and Moore (1958), and develops his own distinctive accent. His key concept is the "aristocratic empire." An aristocracy "... is a ruling class in an agrarian economy that does not engage in productive labor but lives wholly or primarily off the labor of peasants. Hence aristocratic empires must contain not only aristocrats but also peasants who, in turn, live in agrarian primitive societies. Because ... it takes many peasants to support one aristocrat, this also implies that aristocratic empires are necessarily a good deal larger than primitive societies" (Kautsky 1982:24). An important refinement of Lenski is Kautsky's distinction between traditional and commercialized aristocratic empires. A traditional or "pure" aristocratic empire is not yet characterized by "commercialization," that is, it does not yet have a developed class of merchants, financiers, and tax collectors who can take over some of the power of the aristocrats. As far as I am aware, the first New Testament scholar to take note of Kautsky's work was Richard Horsley in an SBL lecture of the late 1980s. For the use of Kautsky see Herzog (1994:53-73); Duling (1995a:160-61); Crossan (1998:157-59). The 2000 SBL Social Science Group had a session centered on the contributions of Lenski and Kautsky to New Testament study. R Rohrbaugh surveyed the use of Lenski and Kautsky in New Testament study and Kautsky was present and responded.

${ }^{25}$ Some other scholars who have seen value in Lenski's modeling are: Cheney (1986); Coote and Whitelam (1986:113-14); Elliott (1986); Oakman (1986, 1994); Saldarini (1988a, 1988b, 1994); Waetjen (1989); Fiensy (1990); Duling (1992a, 1993b:649-654; ch 2); Love (1993, 1994); Seeman (1993); Herzog (1994:53-66); Duling \& Perrin (1994); Knight (1994:115); Craffert (1996); Crossan (1998); Stegemann \& Stegemann (1999); McNutt (2000:245); Carter (2000:18, 561, n 86); cf Osiek (1992:39-43). 
- In 1988 Anthony Saldarini (1988) combined Lenski (1966) and Kautsky (1982) to describe social stratification in Palestinian Judaism. In contrast to Lenski, he stressed the distinction between "social groups" and "classes." 26 For Saldarini the Pharisees were both retainers (a "class") and a social group, while the scribes were retainers but not a social group (in contrast to the gospel redaction). ${ }^{27}$

- In 1995 Ekkehard and Wolfgang Stegemann (1999) used Lenski's analysis as the basis for their views of power, "social systems," the evaluation of "statuses," and the discussion of "status inconsistency" 28 in Palestine, though they preferred the term "stratum" to "class.", Again, the scribes fell in the retainer class (though this class is not so labeled in their model). Scribes are grouped together with members of the Sanhedrin, administrative and military retainers, functionaries, priests, local judges, tax collectors, foreign traders, and wholesalers.

\footnotetext{
${ }^{26}$ What Saldarini called "social groups" are what we discussed above as "status groups" (Weber's Stände). He also used sect and network analysis to analyze the groups. For my position on network analysis, see especially Duling $(1993,1999 b, 2000,2001)$.

${ }^{27}$ Pharisees were of the retainer class, but they were also a political-religious interest group and a sect, as well as a voluntary association (see Saldarini 1988:42, 59, 69, 72, 74). I have discussed the Matthean group as a voluntary association (Duling 1995a), as has Ascough (1998b). Yet, there may have been scribes from the same family over generations (see, e.g., Baker 1994:69).

28 Alföldy (1985) is helpful for the overall picture, but his Roman-oriented stratification is too localized to apply directly to Palestine without modification. For such a modification, see Fiensy (1990 and n 53).

29 "A stratum comprises all the people of a society who find themselves in a similar social position on the basis of their share of power, privilege, and prestige" (Stegemann \& Stegemann 1999:58). See above, note 17 for the debate about "class" as compared with "status."
} 
There are numerous others who use or modify Lenski (and Kautsky), but these two will suffice. I add Shaye Cohen's (1986:47) model in order to highlight my emphasis on the distribution system.

\section{Economic}

I The Rich
A. The city rich
B. The country rich
(owners of large estates)
II. The "Middle Class"
A. Artisans, merchants, etc (city)
B. Owners of moderate Estates (country)
III. The "Lower Class"

A. The city poor

B. The country poor

1. Peasant farmers

2. Landless peasants

IV. "Non-Persons"
A. Women and children
B. Slaves

\section{Religious}

I. Jews
A. The Religious Establishment 1. High priests, priests, and Levites
2. The patriarch and his court
3. Scribes, elders, rabbis, sages, members of the sanhedrin

B. The Sects and "Unofficial" Authority Figures

1. Hasidim, Pharisees, Sadducees, Boethusians, Essenes, Qumran sect, "Fourth Philosophy," JudeoChristians, Samaritans (?), Haberim (?), rabbis (?)

C. Other Jews

1. The "am hā' āretz and other nonsectarian" Jews

2. "Hellenistic Jews"

3. Proselytes

II. Non-Jews
A. The Romans and the Roman army
B. "Greeks," hellenized pagans, not-so- hellenized pagans
C. Samaritans (?) 
Shaye Cohen (1986:47) observed that influential scholars ${ }^{30}$ of the social world of ancient Israelite religion have used two very different, contrasting "grids" for ranking, one "economic," the other "religious" (see also Kampen's review of David Fiensy 1994:207208). ${ }^{31}$ Cohen's economic and religious grids correspond roughly to Lenski's "property class system" and "religious class system." However, note that Cohen did not put scribes in the economic grid, but in the "religious" grid, and rather high: they are part of the "religious establishment." This judgment is based on the perception that scribes were Torah scholars - thus, in the "religious class system" - a matter of some debate, as we shall see.

These three examples to focus on pre-70 CE Palestinian Judaean conditions under the Herods. ${ }^{32}$ This time frame is appropriate for the life of the historical Jesus and the story world of the gospels. ${ }^{33}$ However, according to most scholars the historical and social context of the author of the Matthean gospel is somewhat different. Whether the place was Antioch - that is the majority view, though much debated ${ }^{34}$ - the gospel was almost certainly written after $70 \mathrm{CE}$ when Herodian and priestly power were no longer a major factor. Thus, Lenski's unrevised monomodel should be the preferred model. However, Cohen's analysis suggests that Lenski's distribution system deserves more attention.

${ }^{30}$ Cohen's examples are Schürer, Kriessig, Jeremias, and Baron.

${ }^{31}$ Fiensy (1992:158) adjusted the Lenski model, again for Palestine, by distinguishing between urban and rural, by adding "unclean and degraded," and by inserting subclasses. However, Fiensy intentionally omitted scribes (and social groups such as Josephus' four "philosophies") from "class" ranking altogether. I subsequently added Lenski's percentages and took note of the work of Douglas Oakman (1986) and the economics of ancient Palestine; see Duling (1992a, 1993b, 1995a, 1995b). Arlandson (1997:21-24) based his discussion on my analysis, but adapted the model, not as a Lenski-type pyramid, but as block, which, he thinks, suggests a greater gap between rich and poor; Carter (2000:18) has accepted Arlandson's modification. Lenski himself recognized the inadequacy of any pyramidal model, including his own, because it does not portray the degree of inequality between the top and bottom of the social order (Lenski 1966:285). However, his alternative was to extend the spire of the governing class. I prefer to keep the pyramid and spire, in part because of the metaphor "pyramids of power" derived from Carney (1975:90; see Hanson \& Oakman 1998:67-93) and the general tendency to see hierarchical structures as pyramids of power. One can then illustrate the radical gulf between upper and lower strata by a broken line. See also Crossan (1998).

32 So does Crossan's (1998) recent adaptation.

${ }^{33}$ I have used the Lenski analysis for the Matthean story this way, as well (see Duling 1992a, 1993b, Duling \& Perrin 1994:56). For an application to Mark, see Rohrbaugh (1993a, 1993b).

${ }^{34}$ For the acceptance of Antioch, see Carter (1996, 2000). 
In what follows I accept Lenski's and Saldarini's retainer ranking for scribes in the monomodel but want to add the educational, occupational, and religious class systems. First, however, it is crucial to say more about scribes in Mediterranean society, particularly Judaean scribes.

\section{SOCIAL ROLES AND RANKING OF SCRIBES IN MEDITERRANEAN ANTIQUITY}

So far, I have considered scribes as a single group. Drawing especially on Saldarini, Schams, Richards, and Kloppenborg it is possible to describe at least six kinds of scribes in the ancient literature.

- Royal Scribes and Government Bureaucrats who served the ruling elite directly. In Mesopotamia royal schools for scribes probably existed already in third millennium BCE (Baker 1994:66-67). In ancient Egypt, professional scribes were educated in schools to copy, recite, and memorize documents. They served in the royal court as political and financial administrators and record keepers, sometimes reaching the highest levels of government (Richards 1989:15). Egyptian "royal scribes" can be be documented down into the Ptolemaic period (Richards 1989:15-16). The Greeks developed a similar role, the Basilikos Grammateus. The Romans had "imperial secretaries" promoted to equestrian status (Richards 1989:16-18; on the Romans, see Richards 1989:15-20). Some scholars argue that a comparable picture of government scribes can be drawn for pre-exilic Israel if Temple functions are stressed (Saldarini 1988:243-44; 1992a; Fishbane 1985:25-27; Viviano 1990:55; Heaton 1994; Davies 1995). ${ }^{35}$

- Public and private secretaries. For the larger Greco-Roman world in the Hellenistic period Richards writes that the grammateus is in general:

... a person employed to write out correspondence for another, whether as a professional or only as an amateur, whether with or without financial compensation, whether maintained full-time by one individual or used only

\footnotetext{
${ }^{35}$ It may be that scribal schools for kings and priests existed in Jerusalem prior to the Exile.
} 
for one assignment, and whether used throughout the entire letter writing process or only for preparing the final draft. This definition includes everyone from the public secretaries usually hired in the agora, to the private secretaries usually retained by wealthy persons, to the friend who writes out a letter for another. His skills could range from a minimal competency with the language and/or the mechanics of writing to the highest proficiency at rapidly producing an accurate, proper, and charming letter.

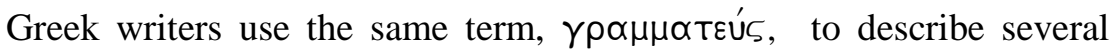
positions. A $\gamma \rho \alpha \mu \mu \alpha \tau \varepsilon u ́ s$ could mean a secretary, public [that is, hired in the agora] or private [that is, usually employed by the wealthy], or a government official. The Latin language is more specialized: scriba denotes a public or official secretary, librarius, a private secretary as does the rarer term amanuensis, and notarius, a shorthand writer.

(Richards 1989:10-11) ${ }^{36}$

- Josephus' references to grammateus reflect this rather broad Greco-Roman "secular" orientation, ${ }^{37}$ which was current in the Judaean Diaspora. ${ }^{38}$

- Village and local scribes. In the Egyptian administrative system there were local

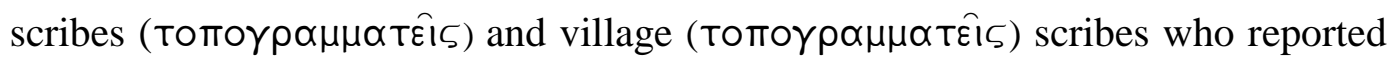
to the "royal scribes" (see Appendix 3). They sometimes cultivated land, but their main functions were administration of the land and processing petitions; they were mainly record keepers and brokers between with higher officials and subordinates (Goodman 1983:59; Richards 1989:15; Kloppenborg 1987:171-245, 342-45; 1991:81-86; Arnal 1995: 482-92; 1997; for the earlier period, see Millard

\footnotetext{
${ }^{36}$ Richards' footnote 59 adds: "In the LXX and the New Testament a third possibility exists: an expert in religious (Jewish and Christian) law." That is the second type in this list. For standing and sitting postures for writing, see Parássoglou (1979).

${ }^{37}$ For Josephus, teachers of the Torah are called sophistai.

38 This view is also found Diaspora texts. In the Letter of Aristeas learned sages are not called "scribes" and the designation of Eleazar, the Jerusalem priestly leader, as "scribe" in Palestinian 2 Maccabees (6:18) has vanished in Diaspora 4 Maccabees (5:4).
} 
1985:303). ${ }^{39}$ Josephus also mentions village scribes (see Saldarini 1992:1014; Horsley 1989:203; Kloppenborg 1989:212-13). ${ }^{40}$ The papyri also show that slaves could be secretaries (see POxy. 3273). ${ }^{41}$ Recent studies have suggested that village scribes copied and transmitted Jesus Move-ment documents such as Q (Kloppenborg 1991:83-85; 1993:25; Arnal 2001:151-55, 170-72) and Mark (Beavis 1989:39-42, 50-67, 167-70).

- Scribes of voluntary associations. There were record-keeping scribes in voluntary associations (Duling 1995a:161-64; Ascough 1998b). Judaean inscriptions from synagogues at Rome suggest that some of these scribes were not highly educated (Saldarini 1992:1016b, derived from Leon 1960). ${ }^{42}$ To these four types of scribes, one may add two special types of scribes often noted in discussions of Israelites.

39 Much information has been retrieved from the wastepaper "archive" of a successor of the Greek Menches, village scribe of Kerkeosiris, Egypt, who reported to the Basilikos Grammateus and whose patron, Dorion, at distant Alexandria, defended him (see Verhoogt 1998, esp 67-68, 70, 88-89 and Appendix 3).

40 JosWars 1.24 .3 (par 479): "Nay, Aristobulus had raised a quarrel between himself and Salome, who was his mother-in-law, besides the anger he had conceived at Glaphyra's reproaches; for he perpetually upbraided his wife with the meanness of her family, and complained, that as he had married a woman of a low family, so had his brother Alexander married one of royal blood. At this Salome's daughter wept, and told it her with this addition, that Alexander threatened the mothers of his other brethren, that when he should come to the crown, he would make them weave with their maidens, and would make those brothers of his country schoolmasters $(\gamma \rho \alpha \mu \mu \alpha \tau \varepsilon \hat{\imath} \zeta)$ and brake this jest upon them, that they had been very carefully instructed, to fit them for such an employment. Hereupon Salome could not contain her anger, but told all to Herod; nor could her testimony be suspected, since it was against her own son-in-law. There was also another calumny that ran abroad and inflamed the king's mind; for he heard that these sons of his were perpetually speaking of their mother, and, among their lamentations for her, did not abstain from cursing him; and that when he made presents of any of Mariamne's garments to his later wives, these threatened that in a little time, instead of royal garments, they would clothe theft in no better than haircloth." (translation in Whiston).

41 Richards (1989:38 n 105), quotes POxy. 724: "Panechotes also called Panares, ex-cosmetes of Oxyrhynchus, through his friend Gemellus, to Apollonius, writer of shorthand, greeting. I have placed with you my slave Chaerammon to be taught the signs which your son Dionysius knows, for a period of two years dating from the present month Phamenoth of the $18^{\text {th }}$ year of Antonius Caesar the lord at the salary agreed upon between us, 120 drachmae, not including feast days; of which sum you have received the first instalment [sic] consisting of 40 drachmae when the boy has learnt the whole system, and the third you will receive at the end of the period when the boy writes fluently in every respect and reads faultlessly, viz., the remaining 40 drachmae. If you make him perfect with the period, I will not wait for the aforesaid limit; but it is not lawful for me to take the boy away before the end of the period, and he shall remain with you after the expiration of it for as many days or months as he may have done no work. The $18^{\text {th }}$ year of the Emperor Caesar Titus Aelius Hadrianus Antoninus Augustus Pius, Phamenoth 5" (italics by Richards).

42 Judaean scribes were keepers of records and contracts and were not highly educated. 
- Elementary Level Bible School Teachers. In the Rabbinic literature the term sopherim could sometimes refer to educators at an elementary level in contrast to learned Torah scholars (reshuth; so Daube 1956:205-23). ${ }^{43}$

- Learned Torah scholars. In second-Temple Israel Ezra was described as a "priest and scribe of the law of the God of Heaven," ${ }^{44}$ thus, a learned Torah scholar (Ezra 7:6; 8:5, 10; Neh 8) and a powerful Judaean political leader (Ezra 7:20, 25). ${ }^{45}$ About 180 BCE Ben Sira sketched the "ideal scribe" as a man of leisure, an international traveler, ambassador, community leader, and expert in all areas of knowledge - thus, a sage and Torah scholar (see further, below). In the

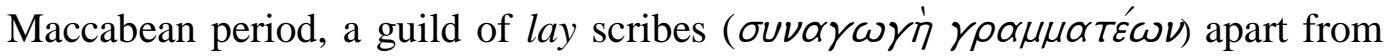
the priests seems to have arisen (1 Macc 7:11). ${ }^{46}$ In the first century BCE 1 Enoch refers to the "scribe of righteousness" (1 Enoch 12:3-4; 15:1) and in the late firstcentury CE 2 Baruch, the apocalyptic visionary Baruch is also a scribe (2 Baruch $2: 1 ; 9: 1-10: 4)$. Finally, in the later Rabbinic literature the "words of the scribes" were still authoritative (Saldarini 1992 vol 5:1015; Hengel 1974:79, 132-16).

As might be expected, these multiple roles and functions have produced a scholarly debate about Judaean scribes. It has tended to focus on whether they were professional writers - copyists, secretaries, and recorders, in or out of government - or Torah scholars with higher power, privilege, and prestige. The former were retainers; the latter, however, should be understood in a different way. From a social-scientific perspective, this debate illustrates competition between the occupational, educational (for Cohen "economic"), and religious class systems and the status ranking in them. The Torah

\footnotetext{
43 Daube is commenting on Mark 1:21-28, that "as one having authority, and not as the scribes" (1:22) and "a new teaching with authority" (1:27) is making the distinction between ordinary teachers (sopherim) and ordained learned scholars (reshuth).

${ }^{44}$ Ezra 7:12; cf Ezra 7:14, 21, in the words of Artaxerxes (cp 7:6) (see North 1992).

${ }^{45}$ Contrast, however, Ezra 10:5; Neh 8:13; 10:1. Thus, scholars debate the point (see, e.g., North 1992).

${ }^{46}$ The scribe was said to be associated with priests and rebels, too.
} 
scholar role for scribe has dominated both Jewish and Christian scholarship ${ }^{47}$ and David Orton's (1989:120) synthetic view follows suit. ${ }^{48}$

However, Christine Schams (1998) has mounted an impressive argument against this widespread view. She notes that Bickerman (1988) called this view a "phantom category" indebted to Luther's translation of grammateus by Schriftgelehrte and that E P Sanders (1992) added that it is a complex scholarly myth with little or no evidence. She argues, first, that the Torah scholar view is a redactional idealization of second-Temple writers without much historical reality, and, second, that New Testament and especially Rabbinic views have been inappropriately read back into the earlier Judaean texts.

In my view, two things need to be observed. First, redactional idealizations, like any literary products, will in some way mirror historical/social realities (e g, Eagleton 1983). Second, redacted idealizations can have a profound effect on later views. Thus, even if the Torah scholar role was an idealization, it may well have had its historical significance and effects. It approximated the role of real scribes and should remain among the normative role options for many scribes in ancient Judaism. As Jonathan Z Smith (1983:168) put it, "The scribes were an elite class of learned, literate men, an intellectual aristocracy which played an invaluable role in the administration of their people in both religious and political affairs

\section{BEN SIRA'S "IDEAL SCRIBE"}

The preceding judgments imply that Ben Sira's idealized scribe (ca 180 BCE), even if exaggerated, should be taken seriously. ${ }^{49}$ Ben Sira, who may have had a scribal school in

47 E g, Christian scholars such as Schürer, Billerbeck, Schlatter, Jeremias, and Hengel. Jewish scholars include Urbach, Bar-Ilan, and Neusner (see the discussion of Schams).

48 For Orton, scribes study Torah, the law of covenants, and the wisdom of the ancients. They penetrate prophecies, the subtleties of parables, and the hidden meanings of proverbs. They offer thanksgiving to God and pray for forgiveness of their sins. They pour forth their own wisdom, showing learning. They meditate on the Lord's mysteries and are filled with the spirit of understanding.

49 Ellis Rivkin (1978:139) once argued that it was precisely Ben Sira who changed the meaning of sopher/grammateus in Judaism to Torah scholar: "The sofer of Ben Sira's day was an intellectual, not a scribe; a scholar, not a copyist; a sage, not a secretary." His image looks much like that of Orton; however, it is precisely this image that Schams contests. 
his house,$^{50}$ sums up the ideal scribe in two poems. Both are thought to reflect the Egyptian "Satire on the Trades." However, Ben Sira's judgment about scribes is less satirical and more positive. ${ }^{51}$ I have summarized the two poems' contrast between scribes and other social groups as follows (Duling 1995a:177).

\section{Scribes}

- Have leisure = opportunity for Wisdom

- are found among and appear before rulers;

- serve among the great

- travel in foreign lands (learn good and evil)

- preserve sayings of the famous

- sit in judge's seat

- understand and make court decisions

- expound discipline and judgment

- are sought out for the people's council

- are eminent in the public assembly

- have names praised by community and nations

\section{Peasants and Artisans}

Peasants:

* work night and day:

- plow furrows

- goad oxen

- talk about cattle

- careful about heifers' fodder

Artisans/Master Artisans:

* labor with their hands into the night to finish their work well

- signet engraver makes exact images

- the smith at the anvil: quality work

- the potter: quantity and quality work

The italicized references can be easily ranked as follows:

"the great"
rulers
scribes
master artisans
artisans
peasants

This social ranking generally matches the ranking of the Lenski macrosocial model for an advanced agrarian society. The scribes are retainers of the elite; they are social brokers.

${ }^{50}$ Ben Sira 51:23: Hebrew: bet-midrāsh; Greek: oikia paideia); Hengel 1974:79, 132.

51 Ben Sira 38:24-34 and 39:1-11 (see Orton 1989:66-67; Skehan \& DiLella 1987:445-53; Saldarini 1988: 254-59; Gammie 1990). 
In the educational and professional class systems they rank relatively high. However, they also appear to be sages/Torah scholars and are thus have even more prestige in the religious class system. Education, professional, and religious roles are fused. As Nickelsburg and Stone (1983:94) put it, Ben Sira's ideal is an "ideal of life which is determined by social role." I now want to reinforce this point about the rank of scribes with "literacy power."

\section{LITERACY, POWER, AND SCRIBES}

The term "scribe" in Hebrew (סופר ) comes from the root פפר which refers to a written message, then a writing, and finally one who could write (Saldarini 1992:1012); the term

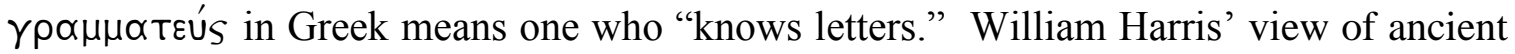
literacy, often cited in this connection, is that probably no more than $10 \%$ of the population of the Greco-Roman world could read and write. ${ }^{52}$ This estimate includes more technical "scribaliteracy," but also less technical "craftsmen's literacy," that is, basic writing for trade or business. ${ }^{53}$

Before proceeding, it is important to address a commonly debated question: was the literacy level of Judaeans ("Jews") higher than other ancient Mediterranean peoples? This question is, in part, a question of education. One eminent authority, A R Millard, ${ }^{54}$ argues on the basis of widespread epigraphic and seal evidence that literacy in Judaean society was widespread. Aaron Demsky agreed. ${ }^{55}$ Ackroyd, Evans, and Bar-Ilan,

\footnotetext{
52 "The likely overall illiteracy level of the Roman Empire under the principate is almost certain to have been above 90\%" (Harris 1989:22, italics mine).

${ }^{53}$ Yaghjian (1996) also discusses "oculiterate reading," that is, the ability to decode a written text, whether one could write or not; "auraliteracy," or correct hearing; and "oraliteracy," or oral memorization and recitation, both of which were still greatly valued in Mediterranean antiquity.

${ }^{54}$ Millard considers his statement in 1972, "writing was theoretically within the competence of any ancient Israelite ... and ... was, in fact, quite widely practiced" (Millard 1972:108) perhaps "too optimistic" (Millard 1985:306), but nonetheless says, "We conclude that few ancient Israelites were out of reach of the written word ...." (Millard 1985:307).

55 "Already by the late Second commonwealth period, elementary education had been organized along communal lines and children were studying in the Beth Sepher - the House of the Book" (response to Millard [352]).
} 
however, hold the opposite opinion (cf Ackroyd and Evans 1970:37; Bar-Ilan 1988:22). Shaye Cohen (1987:120) judges that compulsory education for Judaean children was not likely. Thus, it seems likely that the literacy level of ancient Judaeans and Christ believers probably did not exceed $10 \% .^{56}$

Oral communication was still important in some circles; ${ }^{57}$ others could read without the ability to write; still others possessed "craftsman's literacy." These variants do not vitiate the importance and status of those who were "scribaliterate." The level of sophistication in the Gospel of Matthew surely requires us to focus on scribaliteracy at a very high level, certainly higher than that of artisans, village scribes, and school teachers. Indeed, the Matthean scribe comes very close to the role of Torah scholar - at least in the groups for which he writes. In terms of the distribution system, the Matthean author ranked very high in professional, educational, and religious power - higher than retainer status in the macrosociety.

This point can be reinforced by an analysis of literacy and power. In the Introduction to Literacy and Power in the Ancient World, Bowman and Woolf (1994) offer the following five summary points about the essays in their collection: ${ }^{58}$

\footnotetext{
${ }^{56}$ Millard (1992:339) admits that most reading and writing was carried out by professional scribes .

57 Papias of Hieropolis (ca $150 \mathrm{CE}$ ) is remembered by Eusebius to have said: "For I did not suppose that the things from the books would aid me so much as the things from the living and continuing voice" (Eusebius, Church History 3.5). See the studies of Kelber (1997).

58 They state that many social anthropologists and historians are cautious about overstating the case for the power of literacy and now tend to focus on local case studies, not generalizing grand theory. For these anthropologists and historians "[1]iteracy is not a single phenomenon but a highly variable package of skills in using texts: it may or may not include writing as well as reading and is generally geared only to particular genres of texts, particular registers of language and often only to only some of the languages used in multilingual societies. Moreover, literacy does not operate as an autonomous force in history, whether for change, progress and emancipation or for repression. Literacy does not of itself promote economic growth, rationality or social success. Literates do not necessarily behave or think differently from illiterates, and no Great Divide separates societies with writing from those without it. The invention of writing did not promote a social or intellectual revolution, and reports of the death of orality have been exaggerated" (Bowman \& Woolf 1994:2-3). Their collection is in part an attempt to redress the balance.
} 
1. Power is related to literacy in predominantly two ways:

- Power over texts, which means that "an elite or restricted group determines both the status of particular kinds of texts and also which people or bodies may use them to legitimize their behavior" (Bowman \& Woolf 1994:6) 59 $^{59}$

- Power exercised through texts, which means that texts legitimize deeds and spoken words though their (re)interpretation.

2. Texts unite communities as well as establish and entrench relations of dominance. Indeed, "[g]radations of literacy created and corresponded to gradations in power" (Bowman and Woolf 1994:13).

3. "In the administrative context of the Greek world and the Roman East, the title and position of grammateus often did not simply describe a function but a position with some status and power" (Bowman and Woolf 1994:10).

4. In Judaean and Jesus Movement contexts the Greek and Semitic languages, like Latin and Greek in the Empire, preserved and spread an elite culture that marked social boundaries and reinforced "political and cultural coherence, or group identity" (Bowman and Woolf 1994:12).

5. Finally, in Judaean and Jesus Movement groups "the very act of writing a sacred text could bestow status and power on the scribe" (Bowman and Woolf 1994:12; for a critique of this view, see Schams 1998:58). Such groups were "textual communities" in which a "sacral graphocentrism" was at work.

In short, scribes possessed "literacy power," indeed "Torah scholar power" in Jesus Movement "textual communities," especially when fewer than $10 \%$ were literate. As Goodman (1994:108) puts it, "[p]erhaps the two roles of scribes, as writers and interpreters, were mutually reinforcing." The Matthean scribe possessed such power.

\footnotetext{
59 This power includes restrictions on writing, reading, access, and possession, and sometimes stress education in a sacred language. "The most common justification for such manipulation is religio" (Bowman \& Woolf 1994:12). Their example is florilegia. An analogy in Matthew would be the formula quotations.
} 
The author of the Gospel of Matthew was scribaliterate in an advanced agrarian society, thus a scribe with power. But even more, the old view that he was a Torah scholar in his group is correct. In what sense could one call him "marginal"?

\section{MARGINALITY}

The title of this paper implies the term "marginal." My initial comments above were a first attempt at clarification a decade ago. Here I want to clarify my understanding of marginality further.

First, a comment about models is in order. The simplified macrosocial model of an advanced agrarian society above is a stratification model, thus a vertical model; similarly, the distribution system chart has been imagined in terms of several vertical "class systems" ("the distribution system"). Indeed, Mediterranean social relations themselves have been described as "verticality" (MacMullen 1974:94; cf 51-73) and typified by "pyramids of power" (Carney 1975); "high" and "low" are the ranking categories. Marginality, however, shifts the social-scientific imagination to center and margin, with the potential for concentric circles. Concentric circles are usually conceived in two dimensions on a flat surface, as in a target, and are often employed for microsocial group analysis (see, e.g., Malina 1986:98-126). ${ }^{60}$ It is also possible to describe insiders' views of outsiders from this perspective; when they make value judgments from their limited perspectives, perspectives they believe to be the center, they are "ethno-centric." It is possible to superimpose the vertical and center-margin models in various ways. For example, native judgments about "high" and "low" in the distribution system can be ethnocentric. Thus, Roman rulers might consider themselves to be at both the top and the center.

I now want to shift attention to the center-margin model. First, I sketch the term and concept "marginality" based mainly on the typology of J M Billson (1988). She discusses three types of marginality, to which I have added a fourth:

- $\quad$ structural marginality;

- social role marginality;

60 I have recently used the concentric circle view in network analysis to describe the Jesus Movement (Duling 1999b, 2000, 2001a, 2001b). 
- cultural marginality; and

- ideological marginality.

I begin with structural marginality because it has dominated discussions of marginality (sometimes used in New Testament study without much theoretical reflection ${ }^{61}$ ).

- Structural marginality is ".... the political, social and economic powerlessness of certain disenfranchised and/or disadvantaged segments within societies" (Billson 1988:185; 189). ${ }^{62}$ In Gino Germani’s (1980) analysis of Latin America ${ }^{63}$ marginals are people living in squatter settlements and segregated shantytowns. They are usually the poor and oppressed. They are denied access to goods and services. Often they are ethnic populations. They are less developed groups in contrast to the larger society. Their norms, values, and attitudes contrast with those of the majority culture. Yet, they are not a totally separate class outside the social structure. They therefore represent a type of internal colonialism, "a society within a society." They are usually found in developing countries and in cities, but can also be found in developed countries and in rural settings ("ecological marginality"). ${ }^{64}$

For Germani these marginal persons are normally non-elites dominated by political, economic, and cultural elites; they are usually at the bottom of the social hierarchy. Macro-vertical and center/periphery models coalesce. However - this is an important point - in theory any persons in any social class can be structurally marginal if they are excluded from participating in their expected

\footnotetext{
61 See my initial comments in this article. Billson (1988:185 n 2) notes that a computer search will show the predominance of this form of marginality.

62 Billson cites seventeen studies from 1974 to 1987 . In 1993, as noted at the beginning of this article, I called this "involuntary marginality" (Duling 1993b).

63 Germani is founder of the Gino Germani Institute at the University of Buenos Aires.

64 At the explanatory level, Germani suggests five interrelated causes of marginality: (1) economic and social (esp high unemployment); (2) political (domination by the powerful; limited participation on the basis of class, race, gender, ethnicity); (3) demographic (high population density); (4) cultural (domination of non-elites by elites; neo-[internal]colonialism; urban domination of rural); and (5) psychosocial (feelings of helplessness; powerlessness; status inferiority; inadequate early socialization).
} 
roles (Germani 1980:49). From this perspective, Germani (1980:49) defines structural marginality more broadly “... as the lack of participation of individuals and groups in those spheres in which, according to determined criteria [legitimated norms, values, ideologies], they might be expected to participate", ${ }^{65}$

- Social Role Marginality is defined by Billson (1988:184) as "the product of failure to belong to a [desired] positive reference group." This subcategory has been isolated in part because sociologist Robert Merton (1957) located marginality within "reference group theory." Modern examples are women and minority persons who want to enter professions or positions previously denied them. In antiquity, there is much less potential for upward social mobility, but, to stick with our topic, there are instances of masters sending their slaves to be educated as scribes and of talented lower level scribes being rewarded with a scribal position of higher status.

- "Cultural Marginality" is Billson's social-scientific and more inclusive language for Park's (1931) social-psychological category "Marginal Man” (Billson 1988:184; see also Antonovsky 1956). ${ }^{66}$ Park had immigrants to the USA in mind. He described the Marginal Man as one who is "condemned" to live "in between" two different, antagonistic cultural worlds without fully belonging to either, who is "caught" between two competing cultures. The "Marginal Man" experiences "acceptance or rejection, belonging or isolation, in-group or outgroup," "ambiguities of status and role," and finally "isolation, identity confusion, and alienation." Similarly, Stonequist (1937:3) defined the "Marginal Man" as

\footnotetext{
${ }^{65}$ Implied in this definition is Germani's analysis of three dimensions: (1) the legitimate exercise of social roles (gender, age, civil status, occupation, social status); (2) "objective resources" (material, such as goods and services, and non-material, such as education); and (3) "personal conditions" (attitudes, propensities, motivations, behavior patters, intellectual capacity, and general and technical knowledge). “... [I]n whatever analysis, the interpretation of the data and situations, the empirical research and the diagnosis of marginality must be made explicit with regard to the normative scheme, marginality criteria, and the explanatory system utilized." (Germani 1980:54; italics mine). "The normative scheme" in Germani's definition and analysis refers to "the set of values and norms which define the categories (status), the legitimate, expected, or tolerated areas of participation and the assignment mechanisms of individuals to each category" (Germani 1980:50). While consciousness of being marginal occurs quite easily in a rapidly changing society (such as modern society), Germani's analysis is abstract enough to engage almost any social system that offers competing normative schemes.
}

${ }^{66}$ Park drew many insights from Simmel's (1908) essay on "the stranger." 
“...unwittingly initiated into two or more historic traditions, languages, political loyalties, moral codes, or religions, one of which is more dominant." Those who are culturally marginal do not fully assimilate; thus, they are said to be "inbetween," to have "status incongruence" (Schemmerhorn 1965:407) and psychological uncertainty. In a later book Park (1950) also extended his Marginal Man concept to include races that never fully assimilate. They never become part of "the center," but remain "marginal."

In a recent study Lee $(1995: 48,58)$ accepts the description of marginality as being "in between" two antagonistic worlds without belonging to either. However, he challenges as excessively negative any social-scientific interpretations that describe this "in between-ness" in terms of "maladjustment," "cultural schizophrenia," "excessive self-consciousness," and "extreme race consciousness" (Lee 1995:62-63) ${ }^{67}$ Lee offers more positive evaluations, for example, one can have the experience of being "in both" (sharing both cultures). Paradoxically the culturally marginal person is "in both of them without either being blended" (Lee 1995:62). Lee goes further. One can also experience "in beyond" (at least in a pluralistic society, being a "new marginal person" embodying a holistic state of being): "To transcend or to live in-beyond does not mean to be free of the two different worlds in which persons exist, but to live in both of them without being bound by either of them. The new marginal person is a liberated person, a person who is truly free ... (Lee 1995:63). ${ }^{68}$

\footnotetext{
67 See also Carter (2000:43-45), who in general draws heavily on Duling (1993). In a footnote Billson writes with respect to the so-called "maladjustments" of marginal persons: "The term 'maladjustment' is used here for convenience and lack of a more neutral term which would still embrace multiple potential problems associated with marginality. It is recognized that marginality may in fact produce innovation, creativity, or other positive consequences for individual and/or society ... Nonetheless, the sense in which marginality has been utilized historically (and is used here) implies that the person who experiences a marginal role will be faced with special problems of "adjustment" which others in non-marginal roles will not have to face" (Billson 1988:190, n 4). Billson is obviously aware of the potentially negative sound of the social-scientific analysis of marginality; nonetheless, her analysis is, indeed, subject to the criticism.

${ }^{68}$ Lee could have gone further: the gene pool suggests that the very notion of "race" is rooted in nineteenth century theories of evolution related to Euro-Americans' ethnocentric view of their cultural superiority (Birx 1988). Nonetheless, the race concept persists socially and psychologically.
} 
- "Ideological Marginality" is not really discussed by Billson. ${ }^{69}$ I have derived it from the anthropologist Victor Turner $(1969,1974)$ : who developed it from the ritual process. ${ }^{70}$ In rites of passage individuals or groups are separated, usually physically, from the social system with its accepted statuses or roles marked by law, custom, convention, and ceremonial. They are initiated and then reintroduced into the social system as neophytes with new, often higher, statuses. Turner calls the initiation stage "marginal" or "liminal" (Latin limen: "threshold"). During this stage, initiates are said to be "betwixt and between," "neither here nor there" (Turner 1969:95), status-less, role-less, spontaneous, sexlessness (sometimes symbolized by naked-ness), and anonymous; they experience egalitarianism and intense comradeship.

Turner thinks of this marginality as "anti-structure" in contrast to normative social structure. He also calls it communitas. "For me, communitas emerges where social structure is not" (Turner 1969:126). While communitas is in the first place "spontaneous communitas," and while there is an attempt to make it "normative communitas," it can also be chosen as a utopian vision of society, or ideological communitas (Turner 1969:132). Ideological communitas is thus voluntary "outsiderhood" (Turner 1974:133), the ideal of the ecclesiola in ecclesia. "Communitas is what people really seek by voluntary poverty ... (Turner 1974:266). In short, this is a different sort of marginality and from a different analytical context. It is a marginality of desired vision, or self-styled liminality. It consists of individuals and groups who consciously and by choice live outside the normative statuses, roles, and offices of society (Turner 1974:133).

\section{THE AUTHOR OF MATTHEW AS A "MARGINAL SCRIBE"}

Using these concepts, I now propose to refine the sense in which the scribe who wrote the Gospel of Matthew might have been "marginal."

Lenski's unrevised macromodel is useful for the post-70 Matthean gospel but it needs to be combined with variables in the distribution system. This means that the

\footnotetext{
69 Billson (1988:197) does mention voluntary homelessness..

70 I originally called this marginality "voluntary marginality" (Duling 1993:646-48).
} 
retainer role of the scribe must be interpreted - qualified - with attention to other variables, especially educational, occupational, and religious class rankings.

\subsection{Structural Marginality}

In structural marginality from Germani's perspective, center/marginal and vertical upper/lower class models overlap. Though by definition marginality can occur at any level of the social hierarchy, most marginal persons are at or near the lower end of the social hierarchy. In the Lenski macromodel they are especially the expendables, but include lower peasants and artisans. For Kautsky, their marginality would have been greater because of their loss of land under a new redistribution system. ${ }^{71}$

However, if we broaden the analysis to include Lenski's distribution system, marginals would include suspected enemies of the state (the political class system); impoverished (the property class system); beggars, prostitutes, and unemployed (the occupational class system); those not of one's ethnic group (the ethnic class system); the illiterate and uneducated (the educational class system); pagans (the ethnic and religious class systems); women (the gender class system); and those outside of one's kin group (the family class system). It is possible to glean from the Matthean story examples of such marginal persons: forced laborers, day laborers, some slaves, tenant farmers, poor, those in need of alms, eunuchs, ritually unclean, lepers, a woman with a hemorrhage, women who follow Jesus, the diseased and infirm, the blind, the lame, the deaf, the dumb, the deformed, paralytics, demoniacs, epileptics, bandits and prostitutes. ${ }^{72}$

Seen from the Lenski macromodel a scribe would not have been structurally marginal; he was a retainer of the elite. He was literate, would have had a somewhat higher social status and literacy power. Descriptions of Judaean scribes, even if idealized, could have an even higher status. Though there is a spectrum, they could be educated Torah scholars who played a significant role in political and religious affairs. Ben Sira's ideal scribe certainly contributed to and reinforced this role perception; he

71 See also the analysis of Lenski and Kautsky by Crossan (1998:157-59).

72 Duling (1992a; 1993:653-54); see also Vledder (1997) for a similar application to Mark (cf Rohrbaugh 1993a; 1993b). 
stated that scribes are ranked just below rulers. From the macromodel perspective, scribes were not structurally marginal.

If we take account of the distribution system, a similar picture emerges. In the political class system the Judaean scribe would have been part of the bureaucracy, in the property class system he was moderately wealthy, and in the occupational system he was an administrative official. With respect to gender, scribes were normally male, though according to Eusebius there were some women copyists (Haines-Eitzen 1998:629-46). ${ }^{73}$ With respect to kinship, there may have been some scribal families (Verhoogt 1998:53).

A problem arises, however, when the fuller range of scribes within the occupational class system is considered, for it is necessary to add in village scribes and other, lesser educated scribes, for example, scribes in voluntary associations. Some of these scribes were of relatively low status. Should we see them as structurally marginal in the most common sense? In Lenski's macromodel they are certainly not among the elite. However, neither are they at the lower levels. In micro-contexts - small villages, groups, and the like - they would have a certain amount of status in view of the even lower level of illiteracy. Only in terms of Germani's broader definition - not being permitted to fulfill one's expected role - might one conclude that such scribes were structurally marginal, but that judgment would have pertained to scribes who had had a higher social status - even Torah scholars within Judaism. In other words, an ancient scribe could have been structurally marginal vis-à-vis the macrosociety if he had been excluded from his role as retainer by someone with higher scribal status or some elite patron. From a microsocial perspective, however, such scribes were not marginals. Given levels of literacy in antiquity, even scribes of relatively low status in the macrosociety would have had relatively high status in villages or voluntary associations. What becomes more

\footnotetext{
${ }^{73}$ Eusebius writes: "As that time also Origen's commentaries on the divine scriptures had their beginning at the instigation of Ambrose, who not only plied him with innumerable verbal exhortations and encouragements, but also provided him unstintingly with what was necessary. As [Origen] dictated there

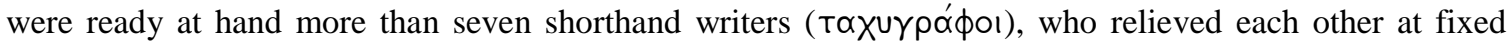

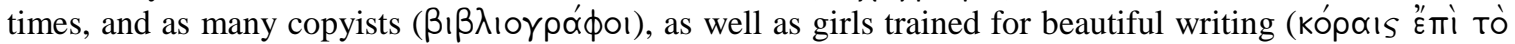

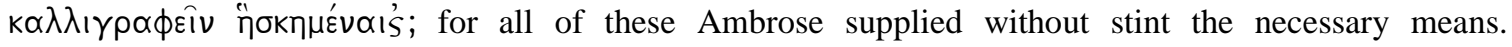
(Eusebius HE 6.23; trans LCC, modified by Haines-Eitzen).
} 
significant, then, are "we-they" judgments of one group by another. That is precisely what we have in relation to the Pharisees and the Matthean group.

Even if the authors of $\mathrm{Q}$ and Mark are considered to be village scribes, as some have suggested, it seems to me that the Matthean author exemplified a higher level scribalism and, indeed, in the traditional Judaean religious context, approximated the role of the Torah scholar. This is indicated by his level of writing, his striking interpretations of the Torah in relation to matters of Judaean concern, his possible bi-lingualism, and his perceived Pharisaic opponents: "their scribes" and "their synagogues." It might be reinforced by his attention to details of wealth and the probability that he was urban. While this description of the Matthean scribe is common in Matthean studies, it also says that from the perspective of structural marginality in the macrosociety the author of Matthew was not a marginal scribe in the most usual sense of that term. It is still possible, of course, that he was marginal in the definitional sense of Germani: he was not fulfilling a role expected of him. However, that is quite conjectural. Most important, in a "textual community" in which a "sacral graphocentrism" was at work - even if the vast majority could not read and the gospel functioned as a guide for community leaders - it suggests that he had scribal power - over texts and through texts.

\subsection{Social role marginality and ideological marginality}

Germani's more inclusive definitional view is similar to Billson's notion of social role marginality, and I would approach it the same way. Had the Matthean writer been denied his social role as a scribe in society at large? It is not impossible, but conjectural. It is tantalizing to suggest that if he had, he would have regained prestige in his social role as a leader of a marginal group that did not conform to the beliefs, norms, and behavior of either the macrosociety or an emergent opponent group (the Pharisees). In such a case, his literacy power would have been transferred, even enhanced, in a "voluntary association" (Duling 1998, 1999a). Thus, ironically, being part of a voluntarily group considered by outsiders to be marginal - ideological marginality - could easily have led to status enhancement. In other words, social role marginality in the macrosociety would have been offset by social role leadership within the Matthean group. While the author's 
scribal leadership in his group can be defended (Duling 1995, 1997), this tantalizing possibility remains, again, speculative.

\subsection{Cultural marginality}

Analyzing the Matthean author from the perspective of cultural marginality is more promising if psychological "maladjustment" analyses are avoided. The description between two or more "historic traditions, languages, political loyalties, moral codes, and religions" fits the Matthean author very well. The most probable cause for his cultural marginality is his ideological marginality, that is, his "voluntary outsiderhood" as a member of a Christ-believing group. ${ }^{74}$ In other words, while he comes from the more literate and educated classes, it aligns him with many who were structurally marginal (the more common sense) in his group, that is, those at the bottom of the social ladder.

This "inbetween-ness" and the conflict, tensions, and stress that accompany seems to pervade the gospel. I illustrate with three major areas of debate and then with several well known examples.

- "Jewish Christianity" or "Christian Judaism"? Had the Matthean group separated from Judaean groups (extra muros) or not (intra muros)? Was this a group still fundamentally within the various Israelite groupings as Kilpatrick, the early Bornkamm, Hummel, W D Davies (and Allison), Goulder, Overman, Saldarini, Levine, and Sim think? Or was it a separatist Jesus Movement group as the later Bornkamm, Stendahl, Schweizer, Hare, Trilling, Strecker, Kümmel, Luz, Stanton, and Hagner believe? ${ }^{75}$ The literature is filled with cautious evaluations and qualifications, so that the former often see some sort of transition beginning to taking place, while the latter often think of some recent separation. The expressions "Christian Judaism" and "Jewish Christianity" have symbolized the

\footnotetext{
${ }^{74}$ I suggested that it is, like the synagogue, a form of voluntary association that goes beyond the faction coalition (Duling 1995a).

75 See the surveys in Rohde (1968); Stanton (1985, 1992); Davies \& Allison (1997); and Senior (1999). For Stanton see (1992a, 1992b): "shortly after a painful separation from Judaism" (p 142). See his remarks about Saldarini and in defense of his "new people"-separatism view (Stanton 1994:17). Hare (2000) has renewed his defense of this position.
} 
fine line issue and some scholars attempt a mediating position. Occasionally referring to my earlier study, Donald Senior titles his recent contribution, "Between two worlds: Gentile and Judaean Christians in Matthew's gospel.",76 I suggest that such "in between-ness" would have been typical of a culturally marginal scribe.

- The Mission. Closely related to this question, scholars have long debated whether the mission is to "the lost sheep of the house of Israel," as Jesus is recorded to have said in the mission speech (Mt 10:6; cp 15:24), or is to "all the peoples," often understood as Gentiles, as the resurrected Jesus finally commands at the end of the story (Mt 28:19). ${ }^{77}$ The difficulty of this question has led to mediating solutions such as a both/and salvation historical sequence, or a both/and Gentile mission that nonetheless is still open to Judaeans, or a both/and Diaspora mission that does not exclude Gentiles. Such ambiguity would have been typical of a culturally marginal scribe.

- Was our scribe himself a Judaean or a Gentile? His focus on the Scripture and Torah matters have led most scholars, especially those who think of the gospel as Judaean, to think of some kind of Judaean author. But would a Judaean have used Hebrew poetic parallelism so oddly and not mention circumcision? ${ }^{78}$ What of the apparent confusion about parties mentioned at the outset of this paper? John Meier (1991:18), who holds that the author was a Gentile, lists in support the views of Clark, Nepper-Christensen, Strecker, Trilling, Walker, Van Tilborg, Pesch, and Franke-mölle, though not all are quite so explicit. I suggest that the author was a marginal Judaean scribe who was "in between" in a variety of ways, thus giving rise to difficulty of answering the question.

These are three major issues in Matthean research, all of which look slightly different under the lens of cultural marginality. Let us briefly note several other possibilities.

\footnotetext{
${ }^{76}$ Senior (1999); near his conclusion he develops my 1993 study of marginality.

${ }^{77}$ On the interpretation of "all the ethne" " as "all the Gentiles," see Hare and Harrington (1975). Recently, see Jackson (2000).

${ }^{78}$ For the view that circumcision is taken for granted in the gospel, see Sim (1996).
} 


\subsection{Consider politics}

On the one hand, there is an implied political conflict with the elite in the story of Herod and the infant Jesus, as Horsley (1989b) has argued, and many anti-elitist political stances lie just under the surface of the story, as Warren Carter $(1004,2000,2001)$ thinks. Yet, Pontius Pilate seems to get off fairly easily. Again, had the author of Matthew held a position in administration at one time? Was he not "in between" with regard to the larger political world?

\subsection{Consider economics}

What was our scribe's position on wealth? On the one hand, Jesus' parable says that those who feed the hungry, give drink to the thirsty, welcome the stranger, clothe the naked, and visit the sick and imprisoned will be rewarded at the judgment. This parable has been seen as a paradigm for the gospel (Mt 25:31-46; see Donahue 1986). Yet, Jesus' beatitude is, "Blessed are the poor in spirit," not "you poor," as in Luke, and in the anointing at Bethany story Jesus observes that, "you always have the poor with you" (Mt 26:11). He consistently uses large sums of money (see Kingsbury 1978). The tendency today is to link the writer with an urban context and wealth. Had he not yet fully identified with the lower level structural marginals in his groups?

\subsection{Consider gender}

Had our scribe moved beyond the patriarchalism of his culture? On the one hand, the faith of the Canaanite woman - also a Gentile - is so great that Jesus heals her daughter (Mt 15:21-28; see Anderson 1983:10-17) and the woman at Bethany will be remembered for her symbolic act (Mt 26:6-13). Yet, the male Jesus and his male disciples control the story and it is men who have the lusty eye (Mt 5:27). Again, while patriarchalism dominates, there are tensions typical of a cultural marginal.

This is only a sampling of possibilities. One might add "between languages,",79 "between Torah conservatism and Torah abandonment," "b0 "between fasting approp-

\footnotetext{
79 The problem is whether his scriptural citations, which represent Hebrew, Aramaic, Greek, and Syriac, represent language versions or simply a text tradition still in flux.

80 Mt 5:17-20 compared with the antitheses in Mt 5:21-48; my view is in Duling (1991).
} 
riately and not fasting at all,"81 and the like. Each in its own way might illustrate the "in between-ness" of the cultural marginal.

The Matthean scribe was culturally marginal. He was clearly "in-between." This seems clear in the "in-between-ness" of his own leadership role. Though he perpetuated the radical Jesus movement tradition, especially represented by Q, he was, in Lucretia Yaghjian's (1996:209) terms, scribaliterate and inserted "have you not read ... ?" into four challenge-riposte settings, which hints at his own view of the power of literacy. ${ }^{82} \mathrm{He}$ asserted his power over sacred texts by his choices of quotations and how they are to be read. He asserted his power through the sacred texts by his notion of fulfillment. He asserted such power also by his redaction of the Jesus sources and traditions. Yet, he was an ideological marginal (and perhaps a social role marginal) who associated with and gave hope to the structurally marginal in the narrower sense. That is one main reason why his narrative is "gospel."

\section{IMPLICATIONS FOR THE MATTHEAN SOCIAL CONTEXT}

What about the Matthean scribe's first readers or hearers? ${ }^{83}$ Recently Richard Bauckham (1999) has put forth the view that scholars have simply assumed but not argued that each evangelist wrote his gospel for one specific community. His alternative proposition is that the gospels were not written for $a$ specific community, as were Paul's letters, but for all the churches of the Jesus Movement. ${ }^{84}$

Graham Stanton's suggestion some years ago, that the First Gospel may have circulated as a "foundation document" in a cluster of Judaean Christ-believing communities, seems to be a middle ground. For Stanton (1994:17), those communities were probably in Syria and the gospel story offered "legitimizing answers" for a "new

\footnotetext{
81 Jesus' disciples are said not to have fasted but the narrative says that Jesus himself did (Mt 4:2) and that the wedding guests would fast after the bridegroom is taken away (Mt 9:14-17); indeed, it offers instructions on how to fast (Mt 6:16-18).

82 Mt 12:3, 5 to Pharisees (about David and the priests); Mt 19:4 to High Priests and (their) scribes (out of the mouth of babes); Mt 21:42 to Pharisees, chief priests, and elders of the people (rejected cornerstone); Mt 22:31 to Sadducees (I am the God of Abraham, Isaac, and Jacob).

${ }^{83}$ For my view on authorial readers and real readers, see Duling (1998, 1999a).

84 My thanks to Andries van Aarde for pointing me to Bauckham's interesting paper.
} 
people." ${ }^{85}$ Stanton's less ambitious regional hypothesis seems to me more likely. Probably an evangelist knew of Christ-believing groups within a particular region. This more limited view fits some things that we know about regionalism, for example, clusters of towns and villages and networking among them.

Elaine Wainwright (1999) suggests that we need to take the $90-95 \%$ of the population, the structurally marginal ones mentioned in the gospel, more seriously. I have listed some of them above.

If we put these two suggestions together, it is possible that local scribal recipients of gospels read them aloud to Christ-believing groups in a particular region and these groups consisted mainly of structurally marginal persons in the usual sense (Paul's majority in 1 Corinthians 1). Indeed, "Let the reader understand" already in Mark

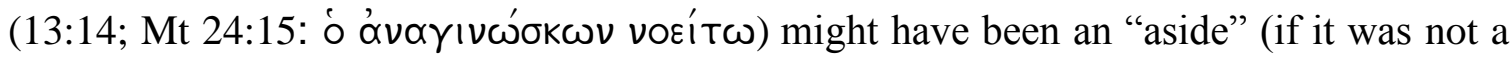
gloss) to a public house-church reader who would need to explain the code language to his assembled listeners. In the Matthean gospel this could be correlated with the many admonitions about right hearing and understanding. ${ }^{86}$ If the author was a scribe, as I have assumed and argued in this paper, there is an analogy in the network of scribes in ancient Egypt (see Appendix 3). If we consider the Matthean scribe to be a Torah scholar with some authority in his network, he may well have written a gospel story that others, perhaps village scribes, would have read to their listeners. The Matthean author might be

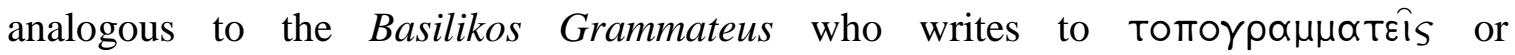

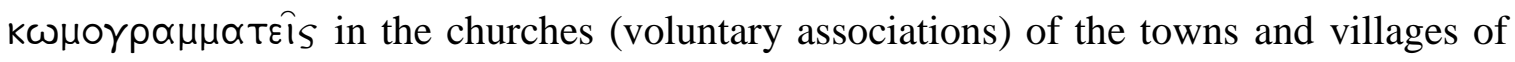
his region (see Appendix 3). ${ }^{87}$

I have suggested that the Matthean scribe was a cultural marginal. His cultural marginality, evidenced by a number of ambiguities, can be found scattered throughout his

\footnotetext{
85 His clearly has Mt 21:43 in mind: "Therefore I tell you, the kingdom of God will be taken away from you and given to a people [" $\varepsilon \theta v \eta]$ producing the fruits of it."

${ }^{86}$ Hearing: 11:15; 13:9, 13, 14, 15, 16, 17, 18, 19, 20, 22, 23, 26, 43; 15:8, 10; 21:16, 33, 45; 22:22, 33; $15: 8,10 ; 21: 16,33,45 ; 22: 23$; understanding: $11: 25 ; 13: 13,14,15,19,23 ; 15: 10 ; 16 ; 24: 15$ (see Wainwright 1999).

87 The Menches archives mention "brother officials" (Appendix 3); curiously, I have argued that the Matthean ekklēsia is something like a brotherhood. In the sense just described, one would have to think of a cluster of churches/brotherhoods.
} 
gospel. That cultural marginality may have grown out of his ideological marginality which identified him, though somewhat incompletely, with the structurally marginal. ${ }^{88} \mathrm{In}$ other words, his "in between-ness" may have grown out of his voluntary association with the have-nots and those who do not participate in the roles expected of them - in those communities where his story was read and heard.

In short, marginality, especially cultural marginality, enhances what it means to be a scribe "instructed for the Kingdom bringing out of his storehouse what is old and what is new."

${ }^{88}$ For my view on ideology and society, see Duling (1997). 


\section{APPENDIX I:}

CASTE, CLASS, AND STRUCTURAL MARGINALITY

To speak of marginality it is necessary to have some conception of the center. In Germani's work that center is the "normative scheme." A complication is that Germani's analysis highlights "modernization" and modern consciousness. A further complication is that to a certain extent the very notion of marginality came about historically because of the industrial revolution and modern conceptions about political freedom, economic development, and secure employment. Thus, one must be cautious in applying such concepts to ancient society. I have assumed that they are useable at a rather high level of abstraction.

Germani says that there are instances where the normative system is so internalized that there is no consciousness of marginality. In such cases a stratified social system is seen as part of the

... natural or divine order, usually rationalized in religious or equivalent terms. This is the case of a caste society...: slaves see themselves as their masters see them. In such a society the very concept of marginality does not emerge as a social perception scheme. In effect, this occurs only when participation becomes problematic or conflicting because there exists more than one normative scheme (or it has become internally incoherent), and/or necessary resources do not exist, or not accessible, and/or members of one or more categories do not possess required personal conditions.

(Germani 1980:52)

Mediterranean society was not a rigid caste society; yet, it was highly stratified and one might make the argument that in some ways it was more like a caste society than a modern society. How acute could the consciousness of marginality have been? Certainly, the existence of political and familial, as well as economic, social, and religious reform movements (factions, parties, sects, philosophical movements, etc) suggests that a marginal consciousness was possible. To help reflect about such questions, consider Germani's Table 1 as a model. Here Germani criss-crosses three possible degrees of participation in the "normative structure" with four possible kinds of consciousness of marginality. 


\section{GERMANI'S TABLE 1 (pp 66-67)}

\begin{tabular}{|c|c|c|c|}
\hline \multicolumn{4}{|c|}{$\begin{array}{l}\text { Degree of participation in terms of power, and/or } \\
\text { prestige, and/or wealth, and/or education, et cetera }\end{array}$} \\
\hline $\begin{array}{l}\text { Consciousness of } \\
\text { one's own and/or } \\
\text { alien marginality }\end{array}$ & $\begin{array}{l}\text { Highly favored } \\
\text { sectors } \\
\text { (elites) } \\
\end{array}$ & $\begin{array}{l}\text { Middle or low } \\
\text { participating sectors } \\
\text { (partial marginality) }\end{array}$ & $\begin{array}{l}\text { Marginal sectors } \\
\text { (generalized } \\
\text { marginality) } \\
\end{array}$ \\
\hline $\begin{array}{c}\text { No consciousness } \\
\text { of } \\
\text { marginality }\end{array}$ & $\begin{array}{l}\text { A } \\
\text { Established con- } \\
\text { servative elites } \\
\text { (strictly defending } \\
\text { the status quo) }\end{array}$ & $\begin{array}{l}\text { B } \\
\text { Middle and/or pop- } \\
\text { ular sectors, es- } \\
\text { tablished, conser- } \\
\text { vative or apathetic } \\
\text { (defending the status } \\
\text { quo) }\end{array}$ & $\begin{array}{l}\mathbf{C} \\
\text { Marginal sectors, } \\
\text { apathetic, and/or } \\
\text { submissive in reli- } \\
\text { gious and/or tradi- } \\
\text { tional terms }\end{array}$ \\
\hline $\begin{array}{l}\text { Consciousness of } \\
\text { only one's own } \\
\text { marginality }\end{array}$ & $\begin{array}{l}\text { D } \\
\text { Partially displaced } \\
\text { elites (intra-elite } \\
\text { conflicts; "palace } \\
\text { rebellions") }\end{array}$ & $\begin{array}{l}\mathbf{E} \\
\text { Partially available } \\
\text { and/or mobilizabile } \\
\text { mass (reformist } \\
\text { movements) }\end{array}$ & $\begin{array}{l}\text { F } \\
\text { Marginal people to- } \\
\text { tally or partially } \\
\text { available and mobil- } \\
\text { izable with propen- } \\
\text { sity to change, } \\
\text { migrate, "develop } \\
\text { the community" } \\
\text { (socio-political } \\
\text { movements) }\end{array}$ \\
\hline $\begin{array}{l}\text { Consciousness of } \\
\text { one's own and } \\
\text { alien marginality }\end{array}$ & $\begin{array}{l}\text { G } \\
\text { Elites partially } \\
\text { displaced (reformist } \\
\text { or revolutionary } \\
\text { propensity in } \\
\text { alliance with other } \\
\text { sectors, exercising } \\
\text { leadership) }\end{array}$ & $\begin{array}{l}\text { H } \\
\text { Available or } \\
\text { mobilizable mass } \\
\text { (reformist or } \\
\text { revolutionary } \\
\text { propensity, in } \\
\text { alliance with other } \\
\text { sectors) }\end{array}$ & (Slightly probable) \\
\hline $\begin{array}{c}\text { Consciousness of } \\
\text { only alien } \\
\text { marginality }\end{array}$ & $\begin{array}{l}\mathbf{J} \\
\text { Established elites } \\
\text { (reformist } \\
\text { tendencies; change } \\
\text { within the } \\
\text { established order) }\end{array}$ & $\begin{array}{l}\mathbf{K} \\
\text { Established middle } \\
\text { and popular sectors } \\
\text { (reformist } \\
\text { tendencies) }\end{array}$ & $\begin{array}{l}\text { L } \\
\text { (Improbable or } \\
\text { impossible) }\end{array}$ \\
\hline
\end{tabular}

One might correlate the three degrees of participation (across the top) with various levels of vertical stratification in the macromodel and distribution system. Consciousness of marginality might be correlated with various types of groups and movements within that society. The author of Matthew might be put in the G quadrant and most structurally marginal persons in the $\mathrm{C}$ and $\mathrm{F}$ quadrants. 


\section{APPENDIX 2:}

\section{CULTURAL MARGINALITY AND CROSS-CULTURAL PSYCHOLOGY}

J W Berry (1990:210) is interested in the degree to which groups or persons in an acculturating group (B) want or do not want to assimilate to the dominant group (A). He posits four degrees of acculturation, only one of which leads to marginality. Reminiscent of the classical formulations of cultural marginality ("the Marginal Man"), he refers to a person who is "trapped between his two possible identity groups, neither accepting nor being accepted by them. As a result he retreats into the social and behavioral sink of marginalization ...." (Berry 1990:218). I have transformed his question-answer datagathering model into quadrants that might be useful for reflecting about antiquity.

IT IS A VALUE TO MAINTAIN

CULTURAL IDENTITY AND

CHARACTERISTICS

IT IS A

VALUE TO

MAINTAIN

RELATION-

SHIPS WITH

OTHER

GROUPS

\begin{tabular}{l|ll} 
& & \\
INTEGRATION & SEPARATION & IT IST A \\
& & VALUE TO \\
MAINTAIN \\
ASSIMILATION & MELATION- & RHIPS WITH \\
& & OTHER \\
& & GROUPS
\end{tabular}

IT IS NOT A VALUE TO

MAINTAIN CULTURAL IDENTITY

AND CHARACTERISTICS

\section{Model: Four Degrees of Acculturation}

Berry wants to illustrate what happens to the behavior of people as a result of culture contact over time. In the following figure the four types of acculturation (vertical axis) are related to phases of developing stress over time (horizontal axis). I have suggested in the paper that statements about psychological "maladjustment" in interpretations of cultural marginality (critiqued by Lee) be replaced by more neutral social-scientific terms from the following figure, that is, conflict, tension, and stress. ${ }^{89}$ In this figure, cultural marginality in Matthew is characterized by conflict and increased tension. ${ }^{90}$

\footnotetext{
${ }^{89}$ For a similar attempt to de-psychologize psychological stress theories themselves, see Duling (2001a).

90 Malina (1986b) has suggested that a degree of sociological ambivalence is culturally acceptable.
} 


\section{HIGH}

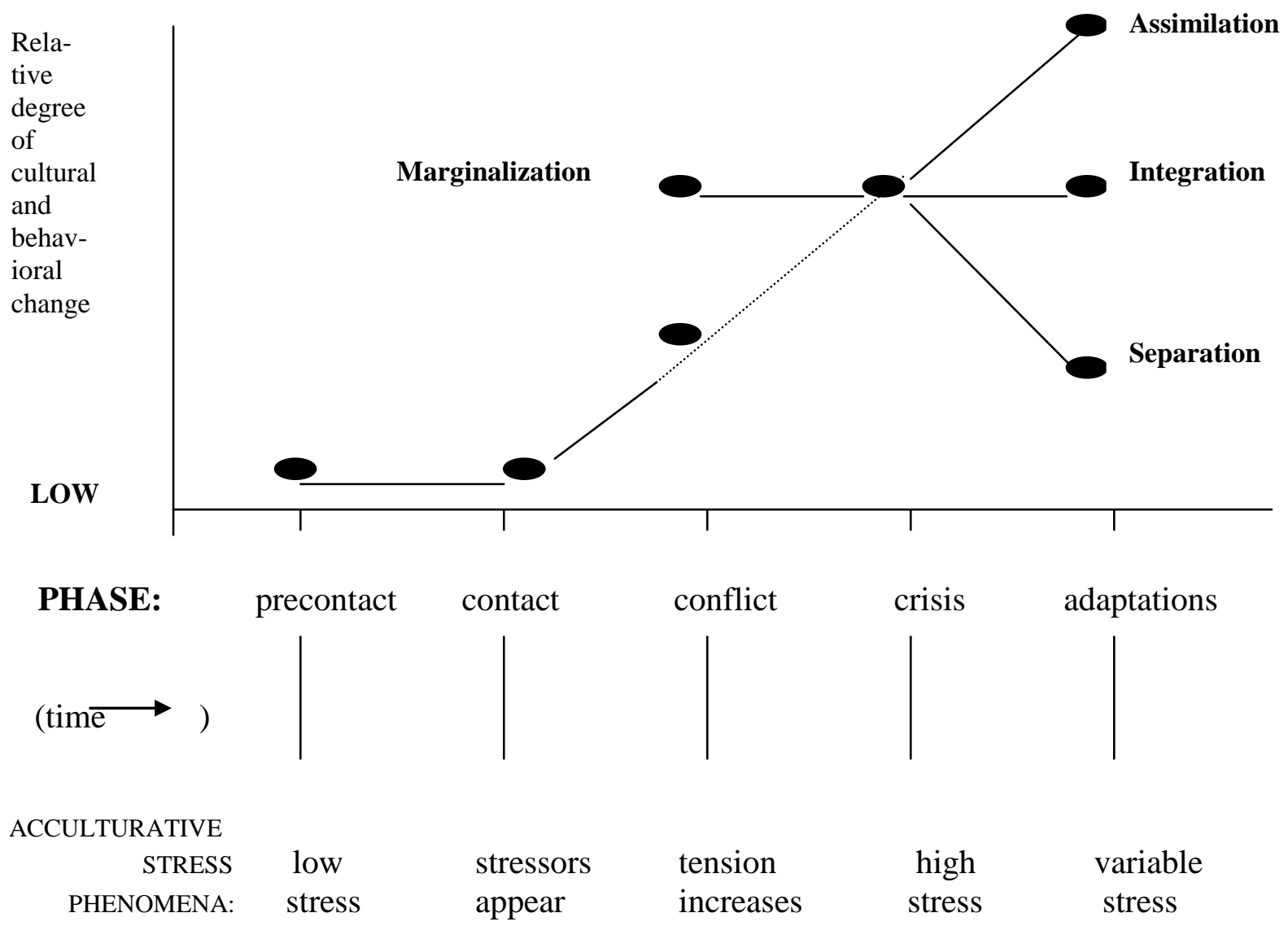

Figure: Degree of Cultural and Psychological Change as a Function of Phases and Varieties of Acculturation

Adopting Berry's cross-cultural social acculturation language of conflict, tension, and stress might help to counteract the "maladjustment" (e g, social illness) language of some interpretations of cultural marginality. 


\section{Appendix 3:}

Country

Dioiketes
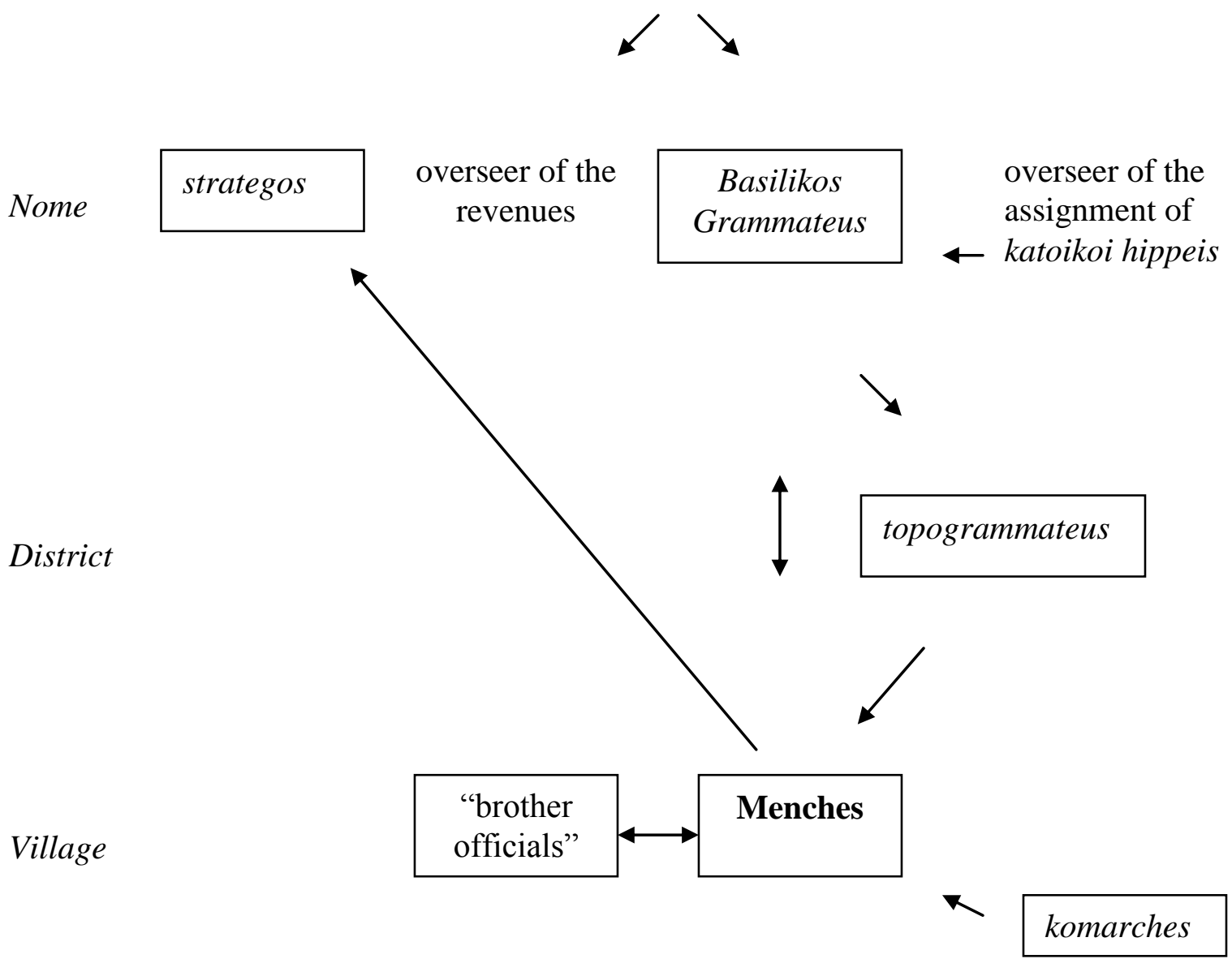

Lines of Correspondence between Menches, the Village Scribe, and his superiors and subordinates (Verhoogt 1998:71) 


\section{Works consulted}

Ackroyd, P R \& Evans, C F 1970. The Cambridge history of the Bible. Cambridge: Cambridge University Press. Vol 1.

Alföldy, G 1985. The social history of Rome, tr by D Braund \& F Pollock. Totowa, NJ: Barnes and Noble Books.

Anderson, J C 1995. Life on the Mississippi: New currents in Matthaean scholarship 1983-1993 [bibliog]. Currents in research: Biblical Studies 3, 169-218 (a version discussed at SBL, 1995) .

Anderson, J C 1998. Response to Donald Senior's "Directions in Matthean Studies." Matthew Group, Society of Biblical Literature, Orlando, Florida, 1998.

Antonovsky, A 1956. Toward a refinement of the "Marginal man" concept. Social Forces 35:57-62.

Arlandson, J M 1997. Women, class, and society in early Christianity: Models from Luke-Acts. Peabody, MA: Hendrickson.

Arnal, W E 1995. The rhetoric of marginality: Apocalypticism, gnosticism, and sayings Gospels. HTR 4, 471-94.

Arnal, W E 1997. Gendered couplets in Q and legal formulations: From rhetoric to social history. JBL 116/1, 75-94.

Ascough, R S 1998. Matthew and community formation. Lecture draft for the William G Thompson memorial, "The gospel of Matthew in current study." Delivered June 13, 1998, at Loyola University of Chicago.

Bacon, B W 1930. Studies in Matthew. New York: Henry Holt.

Baker, D W 1994. Scribes as transmitters of tradition, in Millard, A R, Hoffmeier, J K \& Baker, D W (eds), Faith, tradition, and history: Old Testament historiography in its Near Eastern context, 65-77. Winona Lake, IN: Eisenbrauns.

Bar-Ilan, M 1988. Part two: Scribes and books in the late second commonwealth and rabbinic period, in Sysling, H (ex ed) \& Mulder, M J (ed) Mikra, 21-37. Philadelphia: Fortress Press.

Baron, S W 1952. A social and religious history of the Jews: I, to the beginning of the Christian era; II, Christian Era - The first five centuries. 2nd ed. New York: Columbia University Press. 
Bendix, R 1978. Kings or people: Power and the mandate to rule. Berkeley, CA: University of California Press.

Berry, J W 1990. Psychology of acculturation, in Berman, J J (ed), Nebraska symposium on motivation, 1989, vol 37: Cross cultural perspectives, 201-34. Lincoln and London: University of Nebraska Press.

Bickerman, E 1988. The Jews in the Greek age. Cambridge: Harvard University Press.

Billson, J M 1988. No owner soil: The concept of marginality revisited on its sixtieth birthday. International Review of Modern Sociology 18, 183-204.

Birx, H J 1988. Human variation, adaptation, and ecology, in Birx, Human evolution, 241-48-42. Springfield: Charles C Thomas.

Bornkamm, G 1963. The stilling of the storm in Matthew, in Bornkamm, G, Barth, G \& Held, H J, Tradition and interpretation in Matthew, 52-57, tr by $\mathrm{P}$ Scott. Philadelphia, PA: Westminster Press.

Bowman, A K and Woolf, G (eds) 1994. Literacy and power in the ancient world. Cambridge: Cambridge University Press.

Carney, T F 1975. The shape of the past: Models and antiquity. Lawrence, KA: Coronado Press.

Carter, W 1994. Households and discipleship: A study of Matthew 19-20. JSNT Suppl. 103. Sheffield, England: Sheffield University Press.

Carter, W 1996. Matthew: Storyteller, interpreter, evangelist. Peabody, MA: Hendrickson.

Carter, W 1997b. "Matthew and the margins." Paper delivered at the 1997 Catholic Biblical Association.

Carter, W 2000. Matthew and the margins: A sociopolitical and religious reading. Maryknoll, NY: Orbis.

Carter, W 2001. Matthew and Empire: Initial Explorations. Harrisburg, PA: Trinity Press International.

Cheney, M L 1986. Systemic study of the Israelite monarchy. Semeia 37, 53-76.

Cohen, S J D 1986. The political and social history of the Jews in Greco-Roman antiquity: The state of the question, in Kraft, R A \& Nickelsburg, G W E, Early Judaism and its modern interpreters, 33-56. Atlanta: Scholars Press. 
Cohen, S J D 1987. From the Maccabees to the Mishnah. Philadelphia, PA: The Westminster Press.

Cohen, S J D 1999. The beginnings of Jewishness: Boundaries, varieties, uncertainties. Berkeley: University of California Press.

Cook, M J 1978. Mark's treatment of the Jewish leaders. Leiden: E J Brill.

Coote, R B, \& Whitelam, K W 1986. The emergence of Israel: Social formation and state formation following the decline in late bronze age trade, in Gottwald, $\mathrm{N} \mathrm{K}$ (ed), Social scientific criticism of the Hebrew Bible and its social world: The Israelite monarchy, 107-47. Dacatur, BA: Scholars Press.

Cope, O L 1976. Matthew: A scribe trained for the kingdom of heaven. Washington, DC: The Catholic Biblical Association of America.

Craffert, P F 1996. Relationships between social-scientific, literary, and rhetorical interpretation of texts [NT]. BTB 26, 45-55.

Crossan, J D 1998. The birth of christianity. San Francisco: Harper.

Davies, G I 1995. Were there schools in ancient Israel?, in Day, J, Gordon, R P \& Williamson, H G M (eds), Wisdom in ancient Israel: Essays in honour of $J$ A Emerton, 199-211. Cambridge: University Press.

Davies, P R 1989. The social world of apocalyptic writings, in Clements, R E (ed), The world of ancient Israel: Sociological, anthropological and political perspectives, 251-71. Cambridge: Cambridge University Press.

Davies, P R 1996. Sects and scrolls: Essays on qumran and related topics. Atlanta, GA: Scholars Press.

Donahue, J R 1986. The parable of the sheep and the goats: A challenge to Christian ethics. TS 47.

Donahue, J R 1988. The gospel in parable. Philadelphia: Fortress Press.

Duling, D C 1978. The therapeutic son of David: An element in Matthew's christological apologetic. NTS 24: 392-410.

Duling, D C 1983. Matthew and the problem of authority: Some preliminary Observations, Proceedings 3. Eastern Great Lakes Biblical Society 3, 59-68; reprinted in Explorations. Journal for Adventurous Thought 3 (1984) 15-24, 33-42, in Frost, W P (ed) 1984, New Testament perspectives. Dayton, Ohio: College Press. 
Duling, D C 1992a. Matthew's plurisignificant "Son of David" in social science perspective: Kinship, kingship, magic, and miracle. BTB 22, 99-116.

Duling, D C 1992b. Matthew (Disciple), in vol 4 of The Anchor Bible Dictionary, 6 vols, 618-22 Garden City, NY: Doubleday.

Duling, D C 1991. [Do not Swear] ... by the city of the Great King (Matthew 5:35). JBL 110(2), 271-89.

Duling, D C 1993. Matthew and marginality, in Lovering, E H (ed), Society of Biblical Literature 1993 Seminar Papers 32, 642-71 Atlanta, GA: Scholars Press. Revised and Reprinted in HTS Theological Studies 51(1), 1-30.

Duling, D C 1995a. The Matthean brotherhood and marginal scribal leadership, in Esler, P (ed), Modelling early Christianity: Social-scientific studies of the New Testament in its context, 159-82. London: Routledge.

Duling, D C 1995b. Matthew and marginality. Rev. reprint of 1993 in HTS Theological 51(1), 1-30.

Duling, D C 1997. Egalitarian ideology, leadership, and factional conflict in the Matthean gospel. BTB 27, 124-37.

Duling, D C 1998. Matthew 18:15-17: Conflict, confrontation, and conflict resolution in a "Fictive" kin association, in Society of Biblical Literature 1998 Seminar Papers, Part One, 253-95 Atlanta, GA: Scholars Press.

Duling, D C 1999a. Matthew 18:15-17: Conflict, confrontation, and conflict resolution in a "Fictive" Kin Association. Reprint of 1998 in BTB 29(1), 4-22.

Duling, D C 1999b. The Jesus movement and social network analysis (Part I: The spatial network). BTB 29, 156-75.

Duling, D C 2000. The Jesus movement and social network analysis (Part II: The social network). BTB 29, 3-14.

Duling, D C 2001a. Recruitment to the Jesus movement in social scientific perspective, in Pilch, J J (ed), Social scientific models for interpreting the Bible: Essays by the Context Group in honor of Malina, B J, 132-75. Leiden: Brill.

Duling, D C 2001b. The Jesus movement and network analysis. Forthcoming as one of a collection edited by Malina, B \& Stegemann, W. Fortress Press, tr as "Die Jesusbewegung und Networkanalyse.” Kohlhammer Verlag. (Forthcoming.) 
Duling, D C, \& Perrin, N 1994. The New Testament: An introduction. Fort Worth, TX: Harcourt Brace.

Eagleton, T 1983. Literary theory: An introduction. Minneapolis, MN: University of Minnesota Press.

Edwards, R A 1989. Reading Matthew: The Gospel as narrative. Listening 24(3), 251261.

Eisenstadt, S N 1963. The political systems of empires. New York: The Free Press.

Eisenstadt, S N 1978. Revolution and the transformation of societies: A comparative study of civilizations. New York: The Free Press.

Elliott, J H 1986. Social-scientific criticism of the New Testament and its social world: More on methods and models. Semeia 35, 1-33.

Esler, P F, (ed) 1995. Modelling early Christianity. London: Routledge.

Fiensy, D 1990. The land is mine: The social history of Palestine in the Herodian period. New York, NY: The Edwin Mellen Press.

Fishbane, M 1985. Biblical interpretation in ancient Israel. Oxford: Clarendon Press.

Fishbane, M 1989. From scribalism to rabbinism: Perspectives on the emergence of classical Judaism, Ch 5 in The garments of torah: Essays in Biblical hermeneutics. Bloomington: Indiana University Press. Reprinted in Gammie, J G \& Perdue, L G 1990, The sage in Israel and the ancient near east, 439-56. Winona Lake: Eisenbrauns.

Galt, A H, \& Smith, L J 1976. Models and the study of social change. New York, NY: John Wiley \& Sons.

Gammie, J G 1990. The sage in Sirach, in Gammie, J G \& Perdue, L G (eds), The sage in Israel and the ancient near east, 355-72. Winona Lake, IN: Eisenbrauns.

Garland, D E 1979. The Intention of Matthew 23. Leiden: E J Brill.

Germani, G 1980. Marginality. New Brunswick, NJ: Transaction Books.

Goodman, M 1994. Texts, scribes, and power in Roman Judaea, in Bowman, A K and Woolf, G (eds), Literacy and power in the ancient world, 99-108. Cambridge: Cambridge University Press.

Gundry, R H 1994. On true and false disciple in Matthew 8,18-22. NTS 40, 433-441. 
Haines-Eitzen, 1998. Girls trained in beautiful writing: Female scribes in Roman antiquity and early Christianity. Journal of Early Christian Studies 6, 629-46.

Hanson, K C, \& Oakman, D E 1998. Palestine in the time of Jesus: Social structures and social conflicts. Minneapolis, MN: Fortress Press.

Hare, D R A 2000. How Jewish is the gospel of Matthew? CBQ 62(2), 264-77.

Harris, W V 1989. Ancient literacy. London, England and Cambridge, MA: Harvard University Press.

Heaton, E W 1994. The school tradition of the Old Testament. Bampton Lectures 1994. Oxford and New York: Oxford University Press.

Hengel, M 1974. Judaism and Hellenism, 2 vols, tr by J Bowden. Philadelphia, PA: Fortress Press.

Hertig, P 1997. The Galilee theme in Matthew: Transforming mission through marginality. Missiology 2, 155-163.

Hertig, P 1999. Geographical marginality in the Matthean journeys of Jesus. SBL 1999 Seminar Papers (No 39). Atlanta, GA: Scholars Press.

Herzog, W R II 1994. Parables as subversive speech: Jesus as pedagogue of the oppressed. Louisville, KY: Westminster/John Knox Press.

Hoh, J 1926. Der christliche grammateus (GK) (Mt 13,52). BZ 17, 265-69.

Horsley, R A 1989a. Sociology and the Jesus Movement. New York, NY: Crossroad.

Horsley, R A 1989b. Questions about redactional strata and the social relations reflected in Q, in Lull, D J (ed), SBL 1989 Seminar Papers, 186-203. Atlanta, GA: Scholars Press.

Hummel, R 1963. Die Auseinandersetzung zwischen Kirche und Judentum im Matthäusevangelium. Munich: Kaiser Verlag.

Jackson, G S 2000. Are the "nations" present in Matthew? HTS Theological Studies 56(4), 935-48.

Kampen, J 1994. Discussion of Fiensy, D A, The social history of Palestine in the Herodian period: The land is mine [1991]. Proceedings, Eastern Great Lakes and Midwest Biblical Societies 14, 205-210.

Kautsky, J H 1982. The politics of aristocratic empires. Chapel Hill: The University of North Carolina Press. UMI Books on Demand Reprint (Ann Arbor, MI, 1996). 
Kelber, W 1997. The oral and written gospel. New Introduction. Bloomington, IN: Indiana University Press.

Kiilunen, J 1991. Der nachfolgewillige Schriftgelehrte: Matthäus 8.19-20 im Verständnis des Evangelisten. NTS 37, 268-79.

Kilpatrick, G D 1950. The origins of the gospel according to St Matthew. Oxford: Clarendon Press.

Kingsbury, J D 1978. The verb akolouthein ("to follow") as an index of Matthew's view of his community. JBL 97, 56-73.

Kloppenborg, J S 1986. Blessing and marginality. The "Persecution Beatitude" in Q, Thomas, and early Christianity. Forum 2(3), 36-56.

Kloppenborg, J S 1987. The formation of Q: Trajectories in ancient wisdom collections. Philadelphia: Fortress Press.

Kloppenborg, J S 1989. The formation of Q revisited: A response to Richard Horsley, in D J Lull, (ed), SBL 1989 Seminar Papers, 204-15. Atlanta, GA: Scholars Press.

Kloppenborg, J S 1991. Literary convention, self-evidence, and the social history of the Q people. Semeia 55, 77-102.

Knight, D A 1994. Political rights and powers in monarchic Israel, 93-117 in Knight, D A \& Meyers, C (eds), Ethics and politics in the Hebrew Bible, Semeia 66. Atlanta, GA: Scholars Press.

Lee, J Y 1995. Marginality: The key to multicultural theology. Minneapolis: Fortress Press.

Lemaire, A 1990. The sage in school and temple, in The sage in Israel and the ancient Near East, 165-81. Eisenbrauns: Winona Lake.

Lemaire, A 1992. Writing and writing materials, in (Si-Z) of Freedman, D N (ed), The Anchor Bible Dictionary, Vol 6, 999-1008. New York: Doubleday.

Lenski, G 1966. Power and privilege: A theory of social stratification. Chapel Hill, NC: University of North Carolina Press.

Lenski, G 1988. Rethinking macrosociological theory. American Sociological Review $53,163-71$.

Lenski, G 1994. Societal taxonomies: Mapping the social iniverse. Annual Review of sociology 20, 1-26. 
Lenski, G, \& Lenski, J 1987. Human societies: An introduction to macrosociology. 5th ed. New York, NY: McGraw-Hill. See Nolan \& Lenski 1998 for the $8^{\text {th }}$ ed.

Lofland, J 1977. "Becoming a world-saver" revisited. American Behavior Scientist 20, 805-18. Reprinted, in Richardson, J (ed) 1978, Conversion careers: In and out of the new religions, 10-23. Beverly Hills: Sage.

Lofland, J, \& Stark, R 1965. Becoming a world saver: A theory of conversion to a deviant perspective. American Sociological Review 30, 862-75.

Luz, U 1990. Das Evangelium nach Matthäus, Vol. 2. Zürich: Benziger Verlag.

MacMullen, R 1974. Roman social relations/: 50 BC-AD 284. New Haven: Yale University Press.

Malina, B J 1986a. Christian origins and cultural anthropology: Practical models for biblical interpretation. Atlanta: John Knox.

Malina, B J 1986b. Normative dissonance and Christian origins, in Elliott, J H (ed), Social-scientific criticism of the New Testament and its social world. Semeia 35, 35-59. Decatur, GA: Scholars Press.

McNutt, P1999. Reconstructing the society of ancient Israel. Library of ancient Israel. Lousiville, KY: Westminster John Knox Press.

Meeks, W A 1983. The first urban Christians: The social world of the apostle Paul. New Haven: Yale University Press.

Meier, J P 1991. The vision of Matthew: Christ, church, and morality in the First Gospel. New York: Crossroad (originally 1979).

Merton, R 1957. Social theory and social structure. New York: The Free Press.

Millard, A R 1972. The practice of writing in ancient Israel. BA 35, 98-111; revised in Campbell, E F \& Freedman, D N (eds), The biblical archaeologist reader, vol 4. Sheffield: Sheffield Academic Press.

Millard, A R 1985. An assessment of the evidence for writing in ancient Israel (and responses), in Biblical Archaeology Today, 301-70. Proceedings of the International congress on biblical archaeology. Jerusalem: Israel Exploration Society and American Schools of Oriental research.

Millard, A R 1992. s v Literacy (Israel). ABD 4, 337-40.

Moore, B, Jr 1966. Social origins of dictatorship and democracy: Lord and peasant in the making of the modern world. Boston: Beacon Press. 
Nickelsburg, G, \& Stone, M 1983. Faith and piety in early Judaism: Texts and documents. Philadelphia: Fortress Press.

Nolan, P, \& Lenski, G 1998. Human societies: An introduction to macrosociology. $8^{\text {th }}$ ed. rev ed of Lenski, G 7th ed (1995). Boston, MA: McGraw Hill.

North, R 1992. s v Ezra (Person). IDB 2, 726-28.

Orton, D E 1989. The understanding scribe: Matthew and the apocalyptic ideal. Sheffield: JSOT Press. (JSNT Suppl 25.)

Osiek, C 1992. What are they saying about the social setting of the New Testament? Rev ed. New York: Paulist.

Overman, A 1990. Matthew's Gospel and formative Judaism: The social world of the Matthean community. Minneapolis, MN: Fortress.

Parásslglou, G M 1979. DECIA XEIR KAI GONU: Some thoughts on the postures of the ancient Greeks and Romans when writing on papyrus rolls. Scrittura e civilt'a 3, 5-21.

Park, R E 1928 Human migration and the marginal man. American Journal of Sociology $33,881-93$.

Piper, R A 1955. The language of violence and the aphoristic sayings in Q, in Kloppenborg, J (ed), Conflict and invention: Literary, rhetorical and social studies on the sayings gospel Q, 53-72. Valley Forge, PA: Trinity International Press.

Richards, E R 1989. The secretary in the letters of Paul. Tübingen: JCB Mohr (Paul Siebeck).

Rivkin, E 1978. Scribes, pharisees, lawyers, hypocrites: A study in synonymity. HUCA 49, 135-42.

Rohrbaugh, R L 1993a. The social location of the Marcan audience. BTB 23, 114-127.

Rohrbaugh, R L 1993b. The social location of the Marcan audience. Interpretation 47, 380-395.

Saldarini, A J 1988b. Pharisees, scribes, and Sadducees in Palestinian society: A sociological approach. Wilmington, DE: Michael Glazier.

Saldarini, A J 1992a. s v Scribes. ABD 5, 1012-1016.

Sanders, E P 1992. Judaism: Practice and belief. London: SCM Press. 
Schams, C 1998. Jewish scribes in the second-temple period. Sheffield: Sheffield Academic Press. (JSOT Suppl 291.)

Schermerhorn, R A 1964. Marginal man, in Gould, J \& Kolb, W L (eds), Dictionary of the social sciences, 406-407. New York: The Free Press.

Schweizer, E 1970. Observance of the law and charismatic activity in Matthew. NTS 16, 213-30.

Seeman, C 1993. The urbanization of Herodian Gelilee as an histoprical factor contributing to the emergence of the Jesus movement. MA Thesis, Graduate Theological Union, Berkeley (San Francisco Theological Seminary, under direction of Robert Coote).

Senior, D 1998a. The Gospel of Matthew in current study. Lecture draft for the William G Thompson Memorial, "Directions in Matthean studies". Delivered June 13, 1998, at Loyola University of Chicago.

Senior, D 1998b. Matthean scholarship: Where are we? and where are we going? Lecture, Matthew group SBL (see Janice Capel Anderson).

Senior, D 1999. Between two worlds: Gentile and Jewish christians in Matthew's gospel. $C B Q 61(1), 1-23$.

Sim, D C 1996. Christianity and ethnicity in the gospel of Matthew, in Brett, M G (ed), Ethnicity and the Bible, 171-95. Leiden: Brill.

Simmel http://www.runet.edu/ lridener/DSS/Simmel/STRANGER.HTML

Sjoberg, G 1960. The preindustrial city. New York: Macmillan.

Skehan, P W, \& DiLella, A A 1987. The wisdom of Ben Sira. New York: Doubleday. The Anchor Bible.

Smith, J Z 1983. Wisdom and apocalyptic, in Hanson, P D (ed), Visionaries and their apocalypses, 101-20 London: SPCK. (Issues in Religion and Theology 4).

Stanton, G N 1992a. The Communities of Matthew. Interpretation 46, 79-91.

Stanton, G N 1992b. A gospel for a new people: Studies in Matthew. Louisville, KY: Westminster.

Stanton, G N 1994. Revisiting Matthew's communities, in Lovering, E H Jr (ed), SBL 1994 Seminar Papers, 9-23. Atlanta, GA: Scholars Press. 
Stegemann, E W, \& Stegemann, W 1999. The Jesus movement: A social history of its first century, tr by O C Dean, Jr. Minneapolis MN: Fortress Press.

Stendahl, K [1954] 1968. The School of St Matthew and its use of the Old Testament. 2nd ed. Philadelphia: Fortress.

Stonequist, E V 1937. The marginal man. New York: Charles Scribner's Sons.

Strecker, G 1966. Der Weg der Gerechtigkeit: Untersuchung zur Theologie des Matthäusevangelium. Göttingen: Vandenhoeck \& Ruprecht.

Townsend, J T 1971. Ancient education in the time of the early Roman empire, in Benko, S \& O'Rourke, J J (eds), The catacombs and the Colosseum, 139-163. Valley Forge: Judson Press.

Townsend, J T 1992. Education (Greco-Roman), in Vol 2 (D-G) of Freedman, D N (ed), The Anchor Bible Dictionary, 6 vols, 312-317. New York: Doubleday.

Trilling, W 1964. Das wahre Israel. 3rd ed. Munich: Kösel Verlag. (STANT 10.)

Turner, V 1969. The ritual process. Structure and anti-structure. Chicago: Aldine Publishing Co.

Turner, V 1974. Dramas, fields, and metapahors: Symbolic action in human society. Ithaca: Cornell University Press.

Van Aarde, A G 2001. Fatherless in Galilee: Jesus as Child of God. Valley Forge, PA: Trinity International Press.

Van Tilborg, Sj 1972. The Jewish leaders in Matthew. Leiden: E J Brill.

Verhoogt, A M F W 1998. Menches, komogrammateus of kerkeosiris: The doings and dealings of a village scribe in the late Ptolemaic period (120-110 BC). . Leiden: Brill. (Papyrologica Lugduno-Batava XXIX.)

Viviano, P A 1990. Methodology, chronology, scribes, and inspiration. Biblical Research 25, 51-57.

Vledder, E-J 1997. Conflict in the miracle stories: A socio-exegetical study of Matthew 8 and 9. Sheffield: Sheffield Academic Press. (JSNT 152.)

Waetjen, H C 1989. A reordering of power: A socio-political reading of Mark's gospel. Minneapolis: Fortress Press.

Wainwright, E M 1991. Towards a feminist critical reading of the Gospel according to Matthew. Berlin, Germany: Walter de Gruyter. (BZNW 60.) 
Wainwright, E M 1999. Only to the lost sheep or to all the nations: Social location constructing elites and marginals in the Matthean gospel. Lecture given at Matthew Seminar, SBL, Boston, MA (Nov.).

Walker, R 1967. Die Heilsgeschichte im ersten Evangelium. Göttingen: Vandenhoeck \& Ruprecht.

Weber, M 1978. Economy and society, an outline of interpretive sociology, edited by G Roth \& Wittich, C and tr by E Fischoff et al. ( $4^{\text {th }}$ German edition). Berkeley : University of California Press.

Yaghjian, L B 1996. Ancient reading, in Rohrbaugh, R (ed), The social sciences and New Testament interpretation, 206-20. Peabody, MA: Hendrickson.

Zangwell, I 1909. The melting pot: A drama in four acts. Rev ed 1939. New York: The Macmillan Co. 